УДК 552.113

\title{
ГИДРОТЕРМАЛЬНО-МЕТАСОМАТИЧЕСКАЯ ЗОНАЛЬНОСТЬ, ФЛЮИДНЫЙ РЕЖИМ И ТИПЫ ЗОЛОТОГО ОРУДЕНЕНИЯ УЧАСТКОВ ЭМИ И ЕЛЕНА ЭПИТЕРМАЛЬНОГО РУДНОГО ПОЛЯ СВЕТЛОЕ (ХАБАРОВСКИЙ КРАЙ)
}

\author{
Левочская Дарья Валентиновна 1,2 , \\ levochskayaDV@polymetal.ru

\section{Якич Тамара Юрьевна ${ }^{1}$,} \\ cherkasovatu@tpu.ru \\ Лесняк Дмитрий Викторович1,2 \\ lesnyakdv@polymetal.ru \\ Ананьев Юрий Сергеевич 1 , \\ AnanyevYS@tpu.ru \\ 1 Национальный исследовательский Томский политехнический университет, \\ Россия, 634050, г. Томск, пр. Ленина, 30. \\ 2 Хабаровский филиал АО «Полиметалл УК», \\ Россия, г. Хабаровск, ул. Муравьева-Амурского, 18.
}

\begin{abstract}
Актуальность исследования определяется получением новых данных о вещественном составе, текстурно-структурных особенностях, гидротермально-метасоматической зональности, фрлюидном режиме и типах золотого оруденения двух наиболее контрастных участков эпитермального поля Светлое (Хабаровский край), образованных в разновозрастных материнских породах позднемелового возраста (К2) основного состава хетаниской свиты коньяк-сантонского яруса (участок Эми) и несогласно перекрывающих их породах кислого состава уракской свиты кампан-маастрихского яруса (участок Елена). Выбранные объекты характеризуются различным уровнем эрозионного среза и наиболее полно отражают разнообразие метасоматитов эпитермального поля Светлое от малоизмененных пород хетанинской свиты в пределах участка Эми до сильно измененных, в том числе гипергенными процессами, пород кислого состава, преобладающих на территории участка Елена. Полученные данные играют важную роль для установления класса эпитермальных месторождений, прогноза оруденения на глубину, а также могут быть использованы для выявления поисковых критериев и признаков аналогичных объектов как на территории Охотско-Чукотского вулканического пояса, так и за его пределами. Целью настоящей работы является изучение гидротермально-метасоматической зональности, вещественного состава, текстурно-структурных особенностей, фрлюидного режима, а также фрорм нахождения золота эпитермального рудного поля Светлое на примере двух участков Эми и Елена. Объектами исследования являются руды, метасоматиты и слабоизмененные исходные породы в виде керновых, штуфровых и сколковых проб, отобранных в результате проведения научно-исследовательских работ из восьми скважин и двух действующих карьеров. Породы изучены методами оптической и электронной микроскопии с применением энергодисперсионной спектроскопии, а также методами рентгено-дифракционного анализа, микротермометрии и рамановской спектрометрии. В результате проведенных исследований установлено, что метасоматическая зональность эпитермального поля Светлое включает осевую зону остаточного квариа (вторичные кварциты с различными текстурно-структурными особенностями - мозаичный, перистый, колломорфный, крустификационный) и ореол переслаивающихся линейно-вытянутых зон метасоматитов (алунитовые и диккитовые кварциты), сменяющихся на большем удалении от осевой зоны серицитовыми и иллит-хлоритовыми метасоматитами. Главная и основная доля минерализации связана с монокварцитами. Морфология рудных тел представлена субпластовыми линейными залежами килевидной формы с грибовидными раздувами в палеожерловинах до 110 м. Средняя мощность рудных тел варьирует от 12 до 60 м, длиной до 700 м при ширине 100...240 м. Падение рудных зон пологое, вблизи палеожерловин крутое с неравномерным или весьма неравномерным характером распределения полезного компонента. Среднее содержание золота в рудах 2,5 2/m. Состав гипогенной сульфидной минерализации представлен сульфидами полиметаллов $\mathrm{Cu}, \mathrm{Pb}, \mathrm{Zn}, \mathrm{Fe}$ в виде пирита, галенита, сфралерита, халькопирита и теннантиттетраэдрита. В пределах рудных тел участка Эми минеральная ассоциация сульфиидов гидротермальной стадии составляет более 5 об. \%, отличается разнообразием и обилием теллуридов. Золотое оруденение представлено двумя типами: АиAg и Au-Ag-теллуридным. Au-Ag руды представлены первичньми рудами со средней пробой 900 \%, развитьми в пределах участка Эми, и вторичными (окисленные) рудами с пробой до 1000 \%, преобладающими на участке Елена. По характеру и составу газово-жидких включений в кварие гидротермально-рудный процесс на участке Эми протекал при температурах 260...330 ${ }^{\circ} \mathrm{C}$. Микрокриотермометрические эксперименты участка Елена указывают на температурный интервал гидротермального процесса $200 \ldots 240{ }^{\circ} \mathrm{C}$. По вещественному составу измененных пород, гипогенной сульфидной ассоциации и фрлюидному режиму эпитермальное поле Светлое относится к сульфатно-кислотному и умеренно-кислотному (HS-IS) muny, обнаруживающему перспективу обнаружения порфирового оруденения на глубину.
\end{abstract}

\section{Ключевые слова:}

Гидротермально-метасоматическая зональность, эпитермальные месторождения золота, текстурно-структурные особенности, фрлюидньй режим, эпитермальное рудное поле Светлое, Охотско-Чукоткий вулканический пояс. 


\section{Введение}

Эпитермальные месторождения золота относятся к низкотемпературным $\left(<300{ }^{\circ} \mathrm{C}\right)$ месторождениям малых глубин (<1 км), приуроченным к конвергентным границам активных континентальных окраин [1-8]. Первоначально понятие «эпитермальные месторождения» было введено В. Лингредом [1] как низкотемпературные $\left(<200{ }^{\circ} \mathrm{C}\right)$ месторождения золота, тесно связанные с обильным проявлением теллуридов, антимонидов и селенидов. Впоследствии температурный режим образования эпитермальных месторождений был увеличен до $300{ }^{\circ} \mathrm{C}$ и они стали условно разделяться на три типа в зависимости от состава и характера растворов, участвующих в их формировании: кислотный (high sulfidation - HS), умереннокислотный (intermediate sulfidation - IS) или низкокислотный (щелочной) (low sulfidation - LS) [5, 7, 9]. Важную роль в типизации эпитермальных месторождений играет характер метасоматических преобразований, их текстурно-структурные особенности, вещественный состав гипогенных сульфидов и флюидный режим.

Изучение особенностей вещественного состава и характера зональности околорудных метасоматитов и руд эпитермального поля Светлое на примере двух участков Эми и Елена представляет собой весьма актуальную задачу, учитывая тот факт, что нередко эпитермальные месторождения золота и в частности их «литокапы (lithocaps)» представляют собой верхние части единой продолжающейся на глубине эпитермально-порфировой системы [10]. Под «литокапами (lithocaps)» понимают каменистые покровы (шляпы), центральными частями которых являются области остаточного кварца и ореолы кварц-алунитовых метасоматитов. Они формируются на глубинах менее 500 м от палеоповерхности и контролируются зонами подводящих каналов [7, 11]. Несмотря на то, что согласно данным И.Н. Кигая на территории Востока Азии (Хабаровский край, Приморье, Япония) эпитермальные золото-серебряные месторождения не обнаруживают пространственной и возрастной связи с медно-порфировыми месторождениями ввиду отсутствия последних [12], единичные крупные порфировые месторождения, такие как местоождения Малмыж и Песчанка, на территории Дальнего Востока России все же известны, что повышает потенциал обнаружения последних в пределах изучаемой площади.

Идентификация метасоматической зональности золоторудных месторождений играет важную роль в понимании процессов гидротермального рудообразования $[13,14]$. Эта информация может быть использована для разработки поисковых критериев и признаков аналогичных объектов как на территории Охотско-Чукотского вулканического пояса, так и за его пределами.

В статье рассматриваются два участка эпитермального рудного поля Светлое, наиболее интересных с точки зрения разнообразия и полноты проявлений гидротермально-метасоматических преобразований рудовмещающих пород кислой серии уракской свиты (участок Елена), несогласно перекрывающих более ранние средне-основного состава породы хетанинской свиты (участок Эми). Участки отражают различный уровень эрозионного среза и, как следствие, различную специфику гидротермальнометасоматических преобразований, вещественный и минеральный состав руд, различный флюидный режим, что наиболее достоверно позволит классифицировать рудное поле Светлое и оценить его потенциал оруденения на глубину.

\section{Геолого-структурная позиция}

\section{золоторудного поля Светлое}

Эпитермальное золоторудное поле Светлое приурочено к Ульинскому прогибу, сложенному меловыми вулканическими образованиями ОхотскоЧукотского вулканического пояса $[15,16]$ и занимает две палеовулканические структуры центрального типа (рис. 1). Эти вулканические постройки разновозрастные - северо-западная (вмещает участок Эми) хетанинского времени, а юго-восточная, более молодая, (участки Елена, Тамара, Людмила и Лариса) уракского времени. Хетаниская свита представлена андезитами, андезибазальтами, их агломератовыми лавами, реже туфами. Наиболее широко развиты пироксеновые андезиты темно-серого, почти черного цвета.

Уракская свита несогласно залегает на размытых породах хетанинской свиты. Она сложена стекловатыми и кислыми породами риолитового состава, дацитами, белыми, серовато-сиреневыми и кремовожелтыми игнимбритами, а также различными туфами и туфолавами (рис. 1).

Разрывная тектоника широко распространена в пределах Светлинского рудного поля. Выделяются продольные (относительно простирания ОхотскоЧукотского вулканического пояса) региональные северо-восточные, крупные поперечные северозападные разрывы. Субвулканические интрузии и две палеовулканические постройки с кальдерами проседания тяготеют к узлам сопряжения. В кальдерах этих палеовулканов и на их склонах встречаются различные метасоматиты, в том числе вторичные кварциты. Области с промышленно значимой золотой минерализацией контролируются зонами сочленениями кольцевых разломов, ограничивающих кальдеры проседания, с разломами северо-западного простирания [17-19].

\section{Методы исследования}

Для изучения минерального состава и петрографических особенностей частично измененных пород, руд и метасоматитов в ходе полевых работ было отобрано порядка 250 керновых, штуфтных и сколковых проб из восьми скважин и двух карьеров с двух исследуемых участков. Основная часть проб отбиралась с шагом не более 3 м, охватывая все петрографические разности из керна четырех скважин участка Елена и аналогичного количества скважин участка Эми. Также были взяты сколковые пробы в бортах карьеров Елена и Эми. 
Из образцов были изготовлены шлифы и аншлифы для определения микротекстурных и структурных особенностей, общей минеральной ассоциации, точной идентификации минералов и их ассоциаций. Микроструктурный и элементный анализ проводился на оптическом микроскопе Carl Zeiss и на сканирующем электронном микроскопе Tescan Vega 3 SBU (Чехия, TESCAN), оснащенном приставкой для рентгенофлуоресцентного энергодисперсионного анализа (ЭДС) Oxford X-Max 50 с Si/Li кристаллическим детектором. Ускоряющее напряжение для СЭМ съемки и анализа было 20 кВ с интенсивностью тока зонда в пределах 4...11,5 нА. Локальный рентгеноспектральной анализ выполнялся с предварительной калибров- кой интенсивности зонда $(11,4 \ldots 11,5$ нА) по кобальтовому стандарту при рабочем (фокусном) расстоянии 15 мм. СЭМ фотографии накапливались для двух основных детекторов: вторичных электронов (SE secondary electrons) и обратно-рассеянных электронов (BSE - backscattered electrons), в лаборатории отделения геологии (НИ ТПУ, г. Томск). Глинистые минералы определялись дополнительно с использованием рентгенодифракционного анализа (РДА) на рентгеновском дифрактометре Bruker D2 Phaser с CuK излучением. Порошковые пробы размера менее 10 мкм сканировались в интервале углов $2 \theta 3,70^{\circ}$ с шагом $0,02^{\circ}$, скоростью сканирования 2 с/точка при параметрах измерения 40 кВ и 40 мА.

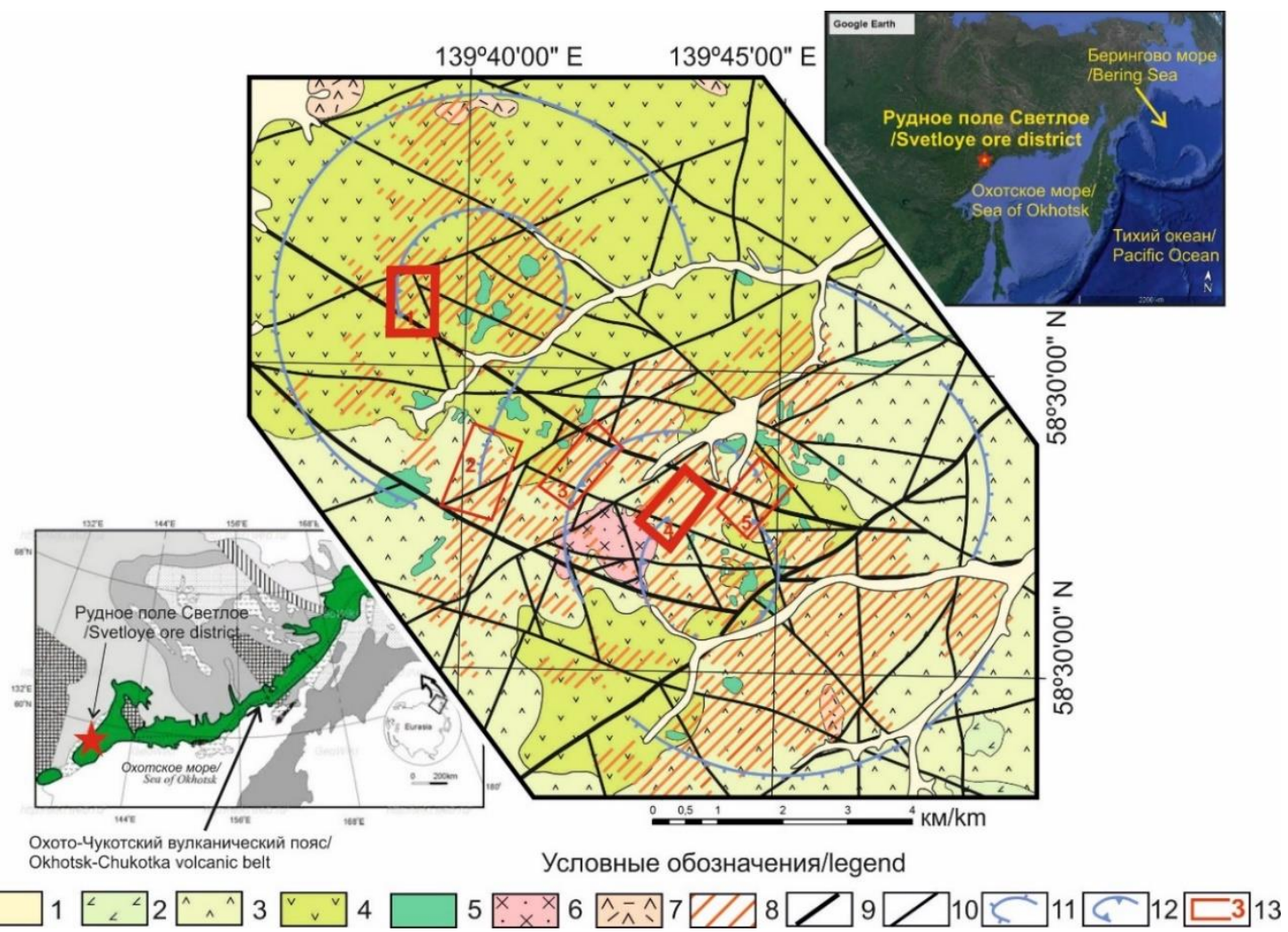

Рис. 1. Схематическая геологическая карта рудного поля Светлое. Составлена с использованием материалов Б.А. Новоселова и ООО «ПД РУС» с добавлениями и корректировками авторов: 1 - современные аллювиальные отложения $\left(Q_{I V}\right) ; 2$ - андезитовые базальты хакаринской свиты $\left(K_{2}\right) ; 3$ - лавы, туфы, игнимбриты уракской свиты $\left(K_{2}\right) ; 4$ - андезитовые лавы, андезибазальты, андезитовые туфы хетанинской свиты $\left(K_{2}\right)$; 5 - штоки и дайки базальтовых андезитов хакаринского базальтового комплекса $\left(K_{2}\right) ; 6,7$ - уракский даичит-риолитовый комплекс $\left(K_{2}\right)$ : 6 - гранодиорит-порфировые штоки; 7 - дацитовые штоки и дайки; 8 - области распространения вторичных квариитов и других метасоматитов; 9, 10 - разломь:: 9 - региональные; 10 - другие; 11 - палеовулканические структуры; 12 - структуры проседания; 13 - участки рудного поля: 1 - Эми, 2 - Людмила; 3 - Тамара, 4 - Елена, 5 - Лариса

Fig. 2. Schematic geological map of the Svetloe ore district. Drawn up by the authors using materials of B.A. Novoselov and «PD RUS» Limited liability Company: 1 - alluvial deposits $\left(Q_{4}\right) ; 2$ - basaltic andesite of the Khakar Suite $\left(K_{2}\right)$; 3 - lavas, tuffs, ignimbrites of the Urak Suite $\left(K_{2}\right) ; 4$ - lavas of andesites, basaltic andesites, andesites tuffs of the Khetanian Suite $\left(K_{2}\right) ; 5$ - stocks and dikes of basaltic andesites of the Khakarinsk basalt complex $\left(K_{2}\right) ; 6,7$ - Urak dacite-rhyolite complex $\left(K_{2}\right)$ : 6 - stock of granodiorite-porphyry; 7 -dacite stocks and dikes; 8 - areas of residual quartz and metasomatic alteration; 9, 10 - faults: 9 - regional; 10 - others; 11 - volcanic structures; 12 - subsidence zones; 13 - areas of deposits: 1-Emmy, 2 -Lyudmila, 3-Tamara, 4-Elena, 5 - Larisa

Для определения температур фазовых переходов, солёности и состава газово-жидких включений проводилась микротермометрия и рамановская спектрометрия двуполированных пластин. Микротермомет- рические исследования флюидных включений проводились с использованием криотермокамеры Lincam THMSG 600 (Великобритания), совмещенной с оптическим микроскопом Carl Zeiss Axio A1, позволяю- 
щей производить измерения температур фазовых переходов в интервале от -196 до $+600{ }^{\circ} \mathrm{C}$ и наблюдать за ними при увеличениях до $500 \times$. При достижении предполагаемых диапазонов фазовых переходов шаг нагрева снижался до $0,1^{\circ} \mathrm{C} /$ мин при точности измерения $0,2{ }^{\circ} \mathrm{C}$ для криометрии и $0,5^{\circ} \mathrm{C}$ для термометрии.

Рамановская спектроскопия осуществлялась с помощью конфокального рамановского спектрометра Thermo Fisher Scientific DXR2. Все измерения проводились при длине волны лазера 785 нм и мощности 20...25 мВт. Спектры обычно получали в течение 5 с для диапазона $0 . .3,364 \mathrm{~cm}^{-1}$ с трехскоростным накоплением.

\section{Результаты и их интерпретация}

Гидротермально-метасоматическая зональность участков Елена и Эми

Золоторудное поле Светлое характеризуется разнообразием гидротермально-метасоматических образований, развивающихся по вулканогенным породам преимущественно кислого состава уракской свиты и, реже, среднего и основного состава хетанинской свиты. В результате петрографического анализа более 160 проб керна скважин с участка Елена и Эми с проведением дополнительных РДА анализов отдельных филлосиликатов были выделены следующие типы метасоматитов: вторичные кварциты (монокварциты, алунитовые, диккитовые, алунит-диккитовые, серицитовые), иллит-хлоритовые и гидрослюдистые кварциты (таблица). Исходные породы были обнаружены только в пределах участка Эми. Они представлены андезибазальтами, андезитами и туфами, преимущественно андезитового состава. Во всех исследованных вулканических образованиях в разной степени проявлены метасоматические изменения, выраженные, прежде всего, в замещении полевых шпатов и темноцветных минералов (роговая обманка, биотит) глинистыми и гидрослюдистыми минералами. Последние можно интерпретировать как аргиллитизацию.

В пределах всего рудного поля Светлое вторичные кварциты слагают разобщенные в плане многослойные залежи неправильной вытянутой формы, имеющие наклонное залегание. Выделяются три группы монокварцитов - массивные, пористые, брекчированные. Распространение тех или иных структурнотекстурных разновидностей монокварцитов отражает изменчивость состава и строения материнских пород. Пористые и брекчированные разности развиваются по наиболее проницаемым породам (например, крупнообломочные туфы, вулканические брекчии), в то время как массивные - по слабопроницаемым (пелитовые туфы, дациты). Наибольшее распространение имеют пористые монокварциты, поровое пространство в которых может оставаться пустым либо быть заполненным кварцем более поздних генераций, рудной минерализаций, сульфатами, филлосиликатами (глинистыми минералами) и др.

В монокварцитовой залежи присутствуют прослои и линейно-вытянутые зоны, сложенные диккитовыми, реже алунитовыми, кварцитами.
Диккит и алунит здесь образуют отдельные включения и их агрегаты, которые заполняют поровое пространство. Значительно реже они развиваются по трещинам, образуя как мономинеральные, так и кварц-диккит-алунитовые прожилки. Процентное содержание диккита и алунита здесь, как правило, составляет 15-20\%.

Монокварцитовые залежи обрамляются алунитовыми кварцитами, при этом на локальных участках (участок Елена, Скв. 2, рис. 2, А, рис. 3) отмечается переход монокварцитов к диккитовым, алунитдиккитовым и алунитовым кварцитам. Внутри алунитовой залежи наблюдается зональное распределение алунита в микрозернистом кварцевом базисе. Это выражается в постепенном увеличении содержания алунита от периферии (20-25\%) к осевой части залежи (до 50 \%). Рост содержания алунита сопровождается уменьшением размеров кристаллов и их более равномерным рассредоточением в основной массе породы - в периферийных частях залежи алунит представлен порфиробластовыми включениями длиннопризматических кристаллов размером до 1 мм, в осевой части - тонкозернистым агрегатом. В алунитовых кварцитах также отмечаются прослои, представленные монокварцитами (вероятно, реликтовые формы от сульфат-насыщенных растворов) и алунит-диккитовыми кварцитами. На участке Эми монокварциты оконтуриваются серицитовыми кварцитами (рис. 2, Б, рис. 4).

Через алунит-диккитовые разности алунитовые кварциты переходят в диккитовые, которые обрамляют залежь вторичных кварцитов, слагая её прикровельную и приподошвенную зоны. На локальных участках диккитовые кварциты оконтуривают монокварциты. Диккит представлен мелкочешуйчатым агрегатом, который заполняет поровое пространство в микрозернистой кварцевой основной массе, а также замещает реликты кристаллокластов. В переходных зонах (к монокварцитам, алунитовым и алунитдиккитовым кварцитам) отмечается развитие относительно крупных таблитчатых кристаллов диккита, которые формируют порфиробластовые включения и заполняют трещины, образуя мономинеральные или алунит-диккитовые прожилки. Диккитовые залежи подстилаются иллит-хлоритовыми метасоматитами, содержание кварца в которых в большинстве случаев не превышает 30 \%. В пределах залежи вторичных кварцитов участка Эми метасоматически измененные вулканические и вулканогенно-обломочные образования слагают крутопадающие линейно-вытянутые зоны, являющиеся останцами первичных вмещающих пород. Эти зоны, ввиду их слабой метасоматической переработки, по-видимому, отражают механически устойчивые и наименее проницаемые области.

Морфология рудных тел и рудовмещающие метасоматически-измененные породы

Рудовмещающими являются монокварциты (массивные, пористые, брекчированные), алунитовые кварциты, алунит-диккитовые кварциты, диккитовые кварциты, иллит-хлоритовые аргиллизиты. 
Таблица. Сводная петрографическая характеристика гидротермально-метасоматических, вулканических и вулканогенно-осадочных образований участка Елена и Эми эпитермального золоторудного поля Светлое

Table. Integrated petrographic characteristics of hydrothermal-metasomatic, volcanic and volcanogenic-sedimentary formations of the Elena and Emmy deposits of the Svetloe gold ore epithermal district

\begin{tabular}{|c|c|c|c|c|}
\hline $\begin{array}{c}\text { Типы } \\
\text { гидротермально- } \\
\text { метасоматических } \\
\text { образований } \\
\text { Types of hydrother- } \\
\text { mal-metasomatic } \\
\text { formations } \\
\end{array}$ & $\begin{array}{l}\text { Минеральный состав } \\
\text { Mineral composition }\end{array}$ & $\begin{array}{c}\text { Структуры пород } \\
\text { Rock structures }\end{array}$ & $\begin{array}{l}\text { Текстуры пород } \\
\text { Rock textures }\end{array}$ & $\begin{array}{c}\text { Текстуры кварца } \\
\text { Quartz textures }\end{array}$ \\
\hline \multicolumn{5}{|c|}{ Участок Елена/Elena deposit } \\
\hline $\begin{array}{l}\text { Монокварциты } \\
\text { массивные } \\
\text { Massive residual } \\
\text { quartz }\end{array}$ & $\begin{array}{l}\text { Кварц/quartz } 80 \ldots 100 \text { \%, глини- } \\
\text { стые минералы/phyllosilicate } \\
0 \ldots 10 \% \text {, рудные минералы } \\
\text { (включая гидроокислы желе- } \\
\text { за)/opaque minerals, including } \\
\text { hydrous ferric oxides } 0 \ldots 15 \%\end{array}$ & $\begin{array}{l}\text { Микрозернистая, реликтовая, } \\
\text { бластопорфировая } \\
\text { Microgranular, relict, } \\
\text { blastoporphyritic }\end{array}$ & $\begin{array}{l}\text { Неоднородная, поло- } \\
\text { счатая, пятнистая, } \\
\text { гнездовая, трещино- } \\
\text { ватая, прожилковая } \\
\text { Heterogeneous, banded, } \\
\text { spotted, nesting, } \\
\text { fractured, veined } \\
\end{array}$ & $\begin{array}{l}\text { Крустификацион- } \\
\text { ная, мозаичная } \\
\text { Crustified, mosaic }\end{array}$ \\
\hline $\begin{array}{l}\text { Монокварциты } \\
\text { пористые } \\
\text { Residual quartz } \\
\text { with vuggy texture }\end{array}$ & $\begin{array}{l}\text { Кварц/quartz } 80 \ldots 100 \% \text {, глини- } \\
\text { стые минералы/phyllosilicate } \\
0 \ldots 5 \% \text {, рудные минералы } \\
\text { (включая гидроокислы желе- } \\
\text { за)/opaque minerals, including } \\
\text { hydrous ferric oxides } 0 . .20 \%\end{array}$ & $\begin{array}{l}\text { Неравномернозернистая, } \\
\text { реликтовая бластопорфировая } \\
\text { Inequigranular, relict } \\
\text { blastoporphyritic }\end{array}$ & $\begin{array}{l}\text { Неоднородная, } \\
\text { пористая, пятнистая, } \\
\text { трещиноватая, плой- } \\
\text { чатая, прожилковая } \\
\text { Heterogeneous, porous, } \\
\text { spotted, fissured, platy, } \\
\text { veined }\end{array}$ & $\begin{array}{l}\text { Крустификацион- } \\
\text { ная, мозаичная, } \\
\text { колломорфная } \\
\text { Crustified, mosaic, } \\
\text { collomorphic }\end{array}$ \\
\hline $\begin{array}{l}\text { Монокварциты } \\
\text { брекчированные } \\
\text { Residual quartz with } \\
\text { brecciated texture }\end{array}$ & $\begin{array}{l}\text { Кварц/quartz } 75 \ldots 85 \% \text {, глини- } \\
\text { стые минералы/phyllosilicate } \\
10 \ldots 15 \% \text {, рудные минералы } \\
\text { (включая гидроокислы желе- } \\
\text { за)/opaque minerals, including } \\
\text { hydrous ferric oxides } 5 \ldots 10 \% \\
\end{array}$ & $\begin{array}{l}\text { Неравномернозернистая, ре- } \\
\text { ликтовая бластопорфировая } \\
\text { Inequigranular, relict } \\
\text { blastoporphyritic }\end{array}$ & $\begin{array}{l}\text { Неоднородная, брек- } \\
\text { чиевидная, пятнистая, } \\
\text { трещиноватая } \\
\text { Heterogeneous, } \\
\text { brecciated, spotted, } \\
\text { fractured }\end{array}$ & $\begin{array}{l}\text { Мозаичная, кру- } \\
\text { стификационная, } \\
\text { колломорфная } \\
\text { Mosaic, crustified, } \\
\text { collomorphic }\end{array}$ \\
\hline $\begin{array}{l}\text { Алунитовые } \\
\text { кварциты } \\
\text { Alunite quartz zone }\end{array}$ & $\begin{array}{l}\text { Кварц/quartz } 50 \ldots 70 \text { \%, алу- } \\
\text { нит/alunite } 20 \ldots 50 \% \text {, рудные } \\
\text { минералы (включая гидроокис- } \\
\text { лы железа)/opaque minerals, } \\
\text { including hydrous ferric oxides } \\
0 . .20 \%\end{array}$ & $\begin{array}{l}\text { Неравномернозернистая, мик- } \\
\text { розернистая гетеробластовая, } \\
\text { реликтовая бластопорфировая, } \\
\text { порфиробластовая } \\
\text { Inequigranular, micro-grained } \\
\text { heteroblastic, relict } \\
\text { blastoporphyritic, porphyroblastic }\end{array}$ & $\begin{array}{l}\text { Неоднородная, пори- } \\
\text { стая, трещиноватая, } \\
\text { пятнистая } \\
\text { Heterogeneous, porous, } \\
\text { fractured, spotted }\end{array}$ & $\begin{array}{l}\text { Крустификацион- } \\
\text { ная, мозаичная } \\
\text { Crustified, mosaic }\end{array}$ \\
\hline $\begin{array}{l}\text { Алунит-диккитовые } \\
\text { кварциты } \\
\text { Alunite dickite quartz } \\
\text { zone }\end{array}$ & $\begin{array}{l}\text { Кварц/quartz } 30 \ldots 50 \% \text {, алунит/ } \\
\text { alunite } 20 \ldots 35 \% \text {, диккит/dickite } \\
20 \ldots 35 \% \text {, рудные минералы } \\
\text { (включая гидроокислы желе- } \\
\text { за)/opaque minerals, including } \\
\text { hydrous ferric oxides } 5 . .10 \%\end{array}$ & $\begin{array}{l}\text { Микрозернистая, гетеробласто- } \\
\text { вая, бластопорфировая, порфи- } \\
\text { робластовая, гранобластовая } \\
\text { Microgranular, heteroblastic, } \\
\text { blastoporphyric, porphyroblastic, } \\
\text { granoblastic }\end{array}$ & $\begin{array}{l}\text { Неоднородная, пори- } \\
\text { стая, трещиноватая, } \\
\text { пятнистая, прожилковая } \\
\text { Heterogeneous, porous, } \\
\text { fractured, spotted, } \\
\text { veined }\end{array}$ & $\begin{array}{l}\text { Крустификацион- } \\
\text { ная, мозаичная } \\
\text { Crustified, mosaic }\end{array}$ \\
\hline $\begin{array}{l}\text { Диккитовые } \\
\text { кварциты } \\
\text { Dickite quartz zone }\end{array}$ & $\begin{array}{l}\text { Кварц/quartz } 50 \ldots 70 \text { \%, } \\
\text { диккит/dickite } 20 \ldots 50 \text { \%, карбо- } \\
\text { натно-гидрослюдистый агре- } \\
\text { гат/carbonate-hydromica } \\
\text { aggregate } 0 . .10 \% \text {, рудные ми- } \\
\text { нералы (включая гидроокислы } \\
\text { железа)/opaque minerals, } \\
\text { including hydrous ferric oxides } \\
0 \ldots 10 \% \text {, барит/barite } 0 . .1 \% \\
\end{array}$ & $\begin{array}{l}\text { Неравномернозернистая, мик- } \\
\text { розернистая, гетеробластовая } \\
\text { Inequigranular, micro-grained, } \\
\text { heteroblastic }\end{array}$ & $\begin{array}{l}\text { Неоднородная, пори- } \\
\text { стая, трещиноватая, } \\
\text { пятнистая } \\
\text { Heterogeneous, porous, } \\
\text { fractured, spotted }\end{array}$ & $\begin{array}{l}\text { Крустификацион- } \\
\text { ная, мозаичная } \\
\text { Crustified, mosaic }\end{array}$ \\
\hline \multicolumn{5}{|c|}{ Участок Эми/Emmy deposit } \\
\hline $\begin{array}{l}\text { Монокварциты мас- } \\
\text { сивные } \\
\text { Massive residual } \\
\text { quartz }\end{array}$ & $\begin{array}{l}\text { Кварц/quartz } 80 \ldots 100 \% \text {, глини- } \\
\text { стые минералы/phyllosilicate } \\
0 \ldots 10 \% \text {, рудные минералы } \\
\text { (включая гидроокислы желе- } \\
\text { за)/opaque minerals, including } \\
\text { hydrous ferric oxides } 0 . .15 \%\end{array}$ & $\begin{array}{l}\text { Неравномернозернистая, ре- } \\
\text { ликтовая бластопорфировая } \\
\text { Inequigranular, micro-grained, } \\
\text { heteroblastic }\end{array}$ & $\begin{array}{l}\text { Неоднородная, поло- } \\
\text { счатая, гнездовая, } \\
\text { трещиноватая, про- } \\
\text { жилковая } \\
\text { Heterogeneous, banded, } \\
\text { nested, fractured, } \\
\text { veined }\end{array}$ & $\begin{array}{l}\text { Колломорфная, } \\
\text { перистая, крусти- } \\
\text { фикационная, } \\
\text { мозаичная } \\
\text { Collomorphic, } \\
\text { feathery, crustified, } \\
\text { mosaic }\end{array}$ \\
\hline $\begin{array}{l}\text { Монокварциты по- } \\
\text { ристые } \\
\text { Residual quartz with } \\
\text { vuggy texture }\end{array}$ & $\begin{array}{l}\text { Кварц/quartz } 80 \ldots 100 \% \text {, глини- } \\
\text { стые минералы/phyllosilicate } \\
0 \ldots 10 \% \text {, рудные минералы } \\
\text { (включая гидроокислы желе- } \\
\text { за)/opaque minerals, including } \\
\text { hydrous ferric oxides } 0 . .15 \%\end{array}$ & $\begin{array}{l}\text { Неравномернозернистая } \\
\text { Inequigranular }\end{array}$ & $\begin{array}{l}\text { Неоднородная, гнез- } \\
\text { довая, пористая, тре- } \\
\text { щиноватая } \\
\text { Heterogeneous, nested, } \\
\text { porous, fractured }\end{array}$ & $\begin{array}{l}\text { Колломорфная, } \\
\text { перистая, крусти- } \\
\text { фикационная, мо- } \\
\text { заичная } \\
\text { Collomorphic, feath- } \\
\text { ery, crustified, mosaic } \\
\end{array}$ \\
\hline $\begin{array}{l}\text { Монокварциты } \\
\text { брекчированные } \\
\text { Brecciate residual } \\
\text { quartz with vuggy } \\
\text { texture }\end{array}$ & $\begin{array}{l}\text { Кварц/quartz } 75 \ldots 85 \text { \%, глини- } \\
\text { стые минералы/phyllosilicate } \\
10 \ldots 15 \% \text {, рудные минералы } \\
\text { (включая гидроокислы железа)/ } \\
\text { opaque minerals, including } \\
\text { hydrous ferric oxides } 5 \ldots 10 \%\end{array}$ & $\begin{array}{l}\text { Микрозернистая } \\
\text { Microgranular }\end{array}$ & $\begin{array}{l}\text { Неоднородная, брек- } \\
\text { чиевидная, пятнистая, } \\
\text { трещиноватая } \\
\text { Heterogeneous, } \\
\text { brecciated, spotted, } \\
\text { fractured }\end{array}$ & - \\
\hline
\end{tabular}


Известия Томского политехнического университета. Инжиниринг георесурсов. 2021. Т. 332. № 10. 17-32 Левочская Д.В. и др. Гидротермально-метасоматическая зональность, флюидный режим и типы золотого оруденения участков ...

\begin{tabular}{|c|c|c|c|c|}
\hline $\begin{array}{l}\text { Алунитовые квар- } \\
\text { циты } \\
\text { Alunite quartz zone }\end{array}$ & $\begin{array}{l}\text { Кварц/quartz } 60 \ldots 70 \% \text {; алу- } \\
\text { нит/alunite } 30 \ldots 40 \%\end{array}$ & $\begin{array}{l}\text { Микрозернистая, гетеробласто- } \\
\text { вая, порфиробластовая } \\
\text { Microgranular, heteroblastic, } \\
\text { porphyroblastic }\end{array}$ & $\begin{array}{l}\text { Неоднородная, про- } \\
\text { жилковая, пятнистая } \\
\text { Heterogeneous, veined, } \\
\text { spotted }\end{array}$ & $\begin{array}{l}\text { Мозаичная } \\
\text { Mosaic }\end{array}$ \\
\hline $\begin{array}{l}\text { Диккитовые квар- } \\
\text { циты } \\
\text { Dickite quartz zone }\end{array}$ & $\begin{array}{l}\text { Кварц/quartz } 75 \ldots 80 \% \text {, дик- } \\
\text { кит/dickite } 15 \% \text {, рудные мине- } \\
\text { ралы/opaque minerals } 5 \ldots 10 \%\end{array}$ & $\begin{array}{l}\text { Неравномернозернистая, } \\
\text { гетеробластовая } \\
\text { Inequigranular, heteroblastic }\end{array}$ & $\begin{array}{l}\text { Неоднородная, тре- } \\
\text { щиноватая, прожил- } \\
\text { ковая } \\
\text { Heterogeneous, } \\
\text { fractured, veined }\end{array}$ & $\begin{array}{l}\text { Мозаичная } \\
\text { Mosaic }\end{array}$ \\
\hline $\begin{array}{l}\text { Гидрослюдистые } \\
\text { кварциты } \\
\text { Hydro-mica quartz } \\
\text { zone }\end{array}$ & $\begin{array}{l}\text { Кварц/quartz } 65 \ldots 70 \% \text {, сери- } \\
\text { цит/white mica } 25 \ldots 30 \% \text {, руд- } \\
\text { ные минералы/opaque minerals } \\
5 \%\end{array}$ & $\begin{array}{l}\text { Микрозернистая, } \\
\text { порфиробластовая } \\
\text { Microgranular, porphyroblastic }\end{array}$ & $\begin{array}{l}\text { Пористая, трещинова- } \\
\text { тая, прожилковая, } \\
\text { пятнистая } \\
\text { Porous, fissured, } \\
\text { veined, spotted }\end{array}$ & $\begin{array}{l}\text { Крустификацион- } \\
\text { ная, мозаичная } \\
\text { Crustified, mosaic }\end{array}$ \\
\hline $\begin{array}{l}\text { Метаандезиты } \\
\text { Altered andesites }\end{array}$ & $\begin{array}{l}\text { Плагиоклаз/plagioclase } \\
50 \ldots 75 \% \text {, вулканическое стек- } \\
\text { ло/volcanic glass } 15 \ldots 35 \% \text {, } \\
\text { кальцит/calcite } 5 \ldots 30 \% \text {, роговая } \\
\text { обманка/hornblende } 5 \ldots 10 \% \text {, } \\
\text { биотит/biotite } 5 \ldots 10 \% \text { хло- } \\
\text { рит/chlorite } 5 \% \text {, серицит/ white } \\
\text { mica } 5 \% \text {, pудные минера- } \\
\text { лы/opaque minerals }<1 . .15 \%\end{array}$ & $\begin{array}{l}\text { Порфировая } \\
\text { Porphyry }\end{array}$ & $\begin{array}{l}\text { Прожилковая, } \\
\text { трещинноватая } \\
\text { Veined, fractured }\end{array}$ & \\
\hline $\begin{array}{l}\text { Метатуфы } \\
\text { Altered tuffs }\end{array}$ & $\begin{array}{l}\text { Плагиоклаз/plagioclase } \\
15 \ldots 40 \% \text {, вулканическое стек- } \\
\text { ло/volcanic glass } 20 \ldots 70 \% \text {, } \\
\text { кальцит/calcite } 10 \ldots 40 \%, \\
\text { кварц/quartz } 5 \ldots 15 \% \text {, ил- } \\
\text { лит+хлорит+cepицит/illite+chlori } \\
\text { te+white mica } 15 \ldots 50 \% \text {, pyдные } \\
\text { минералы/opaque minerals } \\
<1 \ldots 20 \%\end{array}$ & $\begin{array}{l}\text { Литокластическая, кристалло- } \\
\text { кластическая, литокристалло- } \\
\text { кластическая, фельзитовая } \\
\text { Lithoclastic, crystalloclastic, } \\
\text { lithocrystallineclastic, felsic }\end{array}$ & $\begin{array}{l}\text { Массивная, пористая, } \\
\text { флюидальная, про- } \\
\text { жилковая } \\
\text { Massive, porous, fluid, } \\
\text { veined }\end{array}$ & \\
\hline
\end{tabular}

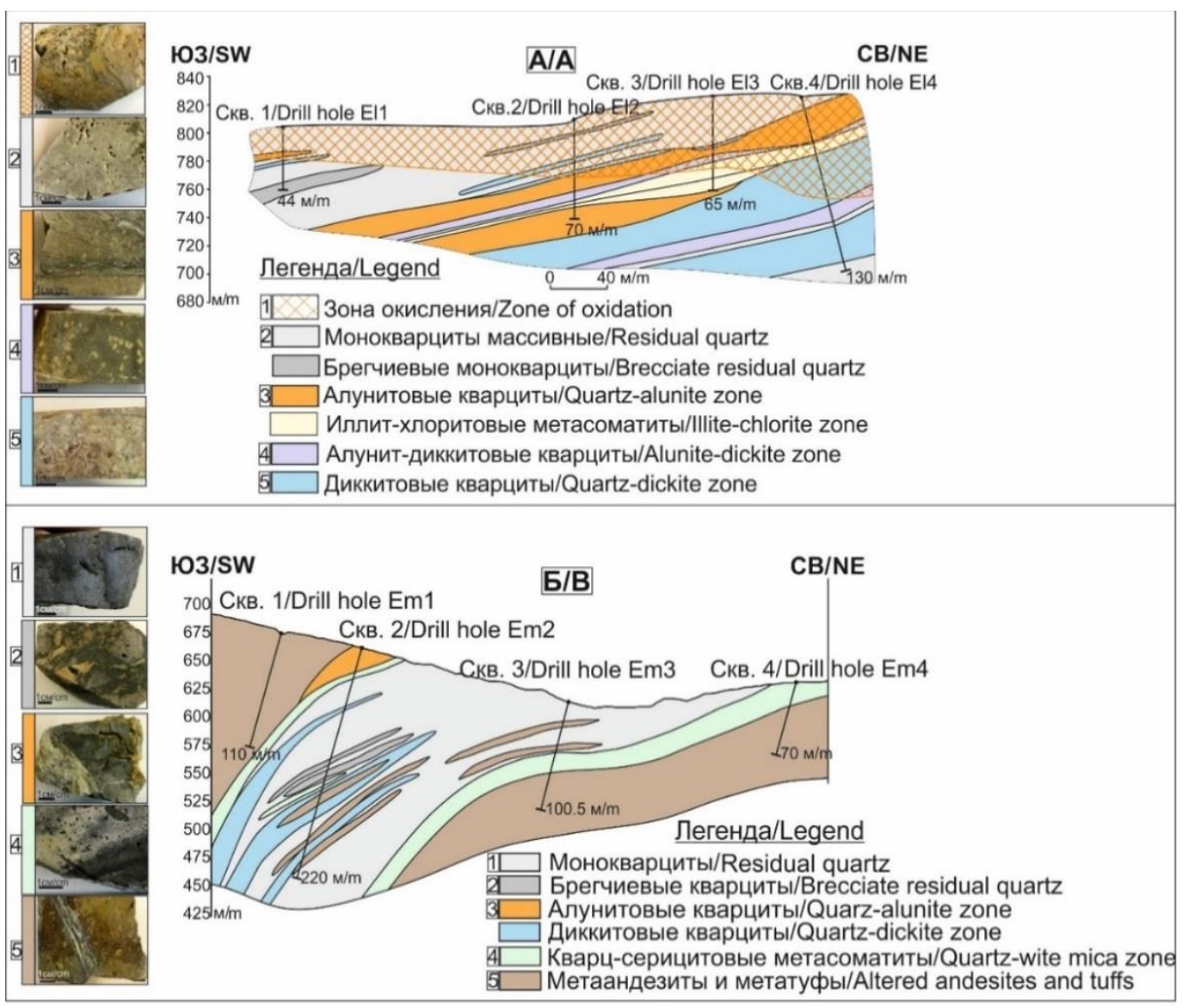

Pис. 2. Схематические разрезы участков Елена (А) и Эми (Б), показывающие вертикальную изменчивость гидротермально-метасоматических образований с наглядным представлением образцов метасоматитов (слева от разрезов)

Fig. 2. Schematic cross sections of alteration zonation within the Elena (A) and Emmy (B) deposits with demonstration of hand specimens (on the left side from the cross sections) 

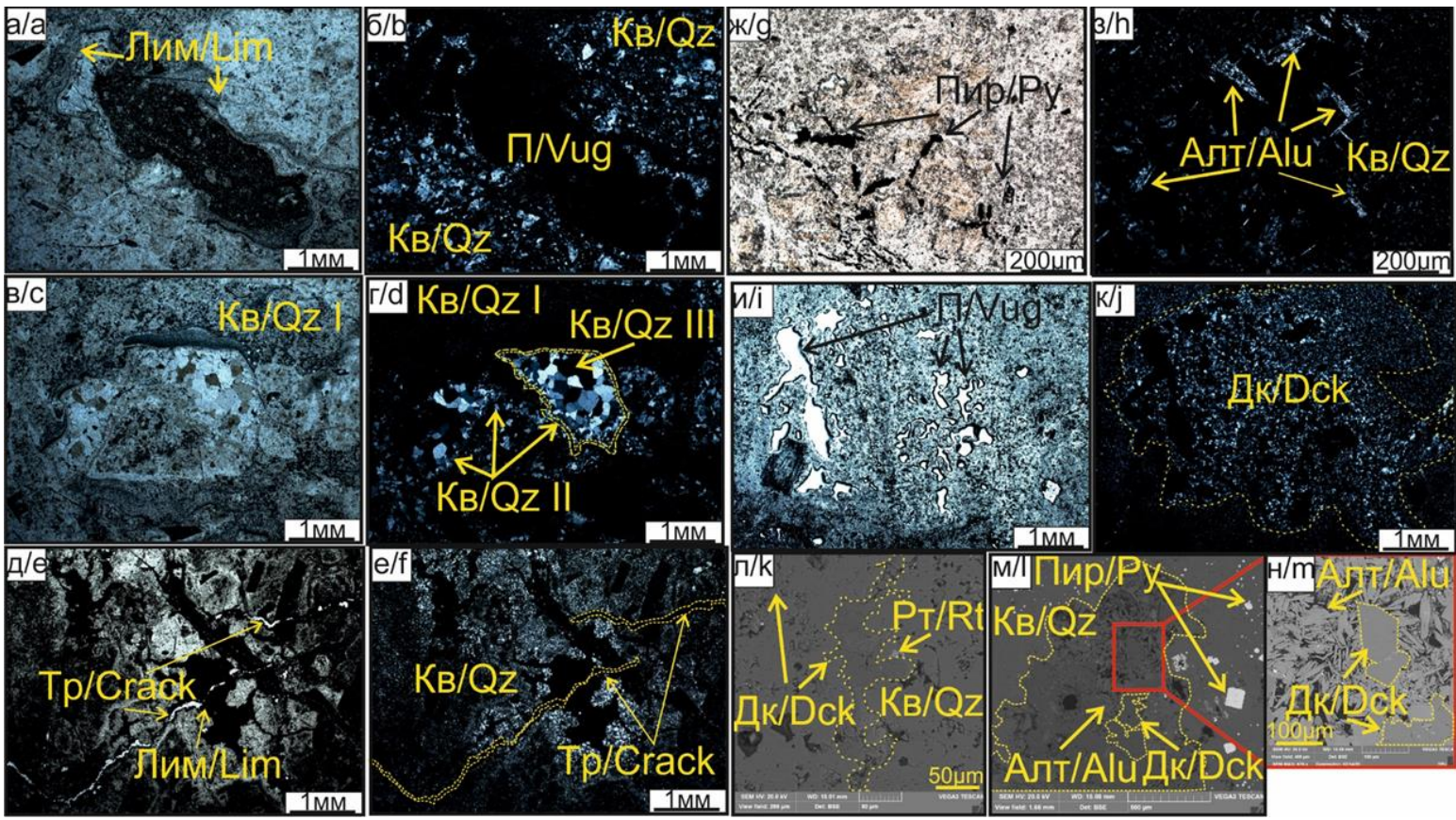

Pис. 3. Фотографии полированных шллиов метасоматитов участка Елена в параллельных (a, в, д, ж, и) и скрещенных

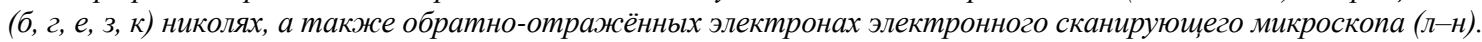
Пористые (П) монокваричиты из поверхностной зоны окисления представлены кварием (Кв) в ассоциации с лимонитом (Лим) (участок Елена, скв. 2, гл. 0,8 м) (а, б); увеличенный фрагмент пористого моноквариита, отражающий несколько генерачий квариа (Кв): микрокристаллический (неразличимозернистый) (I), мелкозернитый - перистый, формируюший структуры обрастания (II), и мелкозернистый мозаичный (III) (участок Елена скв. 2, гл. 0,8 м) (в, г); брегчиевые монокварчиты (Кв) с брегчиево-иементной текстурой и обильным количеством трещин (Тр), частично заполненных гидрокислами железа (Лим) (участок Елена, скв. 2, гл. 11,3 м) (д, е); алунитовый (Алт) квариит (Кв) с вкрапленностью рудных минералов, представленных преимущественно пиритом (Пир) (участок Елена, скв. 2, гл. 55,7 м) (ж, з); диккитовые кварииты (Кв), где диккит (Дк) заполняет гнезда и пустоты выщелачивания (П) в кварие (Кв) (участок Елена, скв. 4, гл. 61,3 м) (и, к); увеличенный фрагмент предыдущего образиа диккитовых квариитов в обратно-отраженных электронах сканирующего микроскопа, демонстрирующий зерно диккита (Дк) в ассочиачии с рутилом (Рm) на фоне квариа (Кв) (участок Елена, скв. 4, гл. 61,3 м) (л); алунит (Алт)-диккитовые (Дк) кварииты (Кв) с вкраплениями пирита (Пир) кубического габитуса (участок Елена, скв. 2, гл. 41,3 м) (м); увеличенный фрагмент предылущего участка, показываюший тесные взаимоотношения вытянутых кристаллов алунита с доменными агрегатами диккита, выполняюшими пустоты выщелачивания в кварие (участок Елена, скв. 2, гл. 41,3 м) (н)

Fig. 3. Transmitted-light microphotographs of altered rocks within the Elena deposit in plane $(a, c, e, g$, $i)$ and crosspolarized $(b, d, f, h, j)$ light, and backscatter electron images $(k-m)$. Residual quartz $(Q z)$ with vuggy (Vug) texture from zone of oxidation represented by quartz $(Q z)$ in association with limonite (Lim) (d. Elena, drill hole El2, depth $0,8 \mathrm{~m})(a, b)$; an enlarged fragment of residual quartz, reflecting various generations of quartz $(Q)$ : microcrystalline (indistinguishable) (I), fine-grained - pinnate, forming fouling structures (II), and fine-grained mosaic (III) (d. Elena, drill hole El2, depth $0,8 \mathrm{~m})(c, d)$; brecciate residual quartz $(Q z)$ with a brecciate-cement texture and an abundant number of cracks in places filled with iron hydroxides (Lim) (d. Elena, drill hole El2, depth 11,3 m) (e, f); quartzalunite (Alu) zone with dissemination of opaque minerals, represented mainly by pyrite (Py) (d. Elena, drill hole El2, depth $55,7 \mathrm{~m})(\mathrm{g}, \mathrm{h})$; dickite-quartz zone, where dickite (Dck) fills nests and cavities of leaching (Vug) in quartz ( $Q z)$ (d. Elena, drill hole El4, depth 61,3 m) $(i, j)$; backscatter electron image of enlarged fragment of the previous dickitequartz zone, demonstrated dickite grains $(D c k)$ in the association with rutile $(R t)$ in quartz $(Q z)(d$. Elena, drill hole El4, depth $61,3 \mathrm{~m})(\mathrm{k})$; alunite $(A l u)$-dickite $(D c k)$ quartz $(Q z)$ zone with dissemination cubic crystals of pyrite $(P y)$ (d. Elena, drill hole El2, depth $41,3 \mathrm{~m})(\mathrm{l})$; enlarged fragment of the previous section showing the close relationship of elongated alunite (Alu) crystals with domain structure aggregates of dickite (Dck), filling leaching cavities in quartz (d. Elena, drill hole El2, depth 41,3 m) (m)

Морфология рудных залежей представляет собой субпластовые линейные залежи килевидной формы с грибовидными раздувами. Параметры рудных залежей существенно изменчивые, длиной до 700 м и шириной $100 . .240$ м, мощностью $12 \ldots 60$ м, с раздувами в палеожерловинах до 110 м, вертикальный размах достигает 300 м. Падение рудных зон пологое, вблизи палеожерловин крутое с неравномерным или весьма неравномерным характером распределения полезного компонента. Струк-

тура руд: микро- и мелкозернистая, порфировидная, гипидиоморфнозернистая, колломорфная. Текстура руд: прожилковая (микропрожилковая), гнездовая, крустификационная, брекчиевидная, полосчатая.

\section{Текстурные особенности кварца}

Текстуры жильного кварца, наблюдаемого во всех разновидностях вторичных кварцитов, представлены четырьмя типами - крустификационный, мозаичный, 
перистый, колломорфный (рис. 5). Наиболее широко распространен крустификационный кварц, развивающийся по стенкам порового пространства и трещин (рис. 5, $a-b$ ). Этот текстурный тип жильного кварца отмечен во всех вторичных кварцитах, за исключением брекчированных монокварцитов. Крустификационный кварц формировался преимущественно по открытому поровому пространству, отвечающему стадии кислотного выщелачивания. Колломорфный (рис. 5, г), мозаич- ный (рис. 5, $)$ и и перистый (эвгедральный) (рис. 5, ж-к) жильный кварц формируется на более поздних стадиях гидротермального процесса при перенасыщении раствора, которое может происходить при его вскипании, а также при быстром падении температуры и/или давления [20]. Наиболее ранним из них является колломорфный кварц, который обрамляется более крупнокристаллическим кварцем мозаичной и перистой текстур (рис. 5, 2).

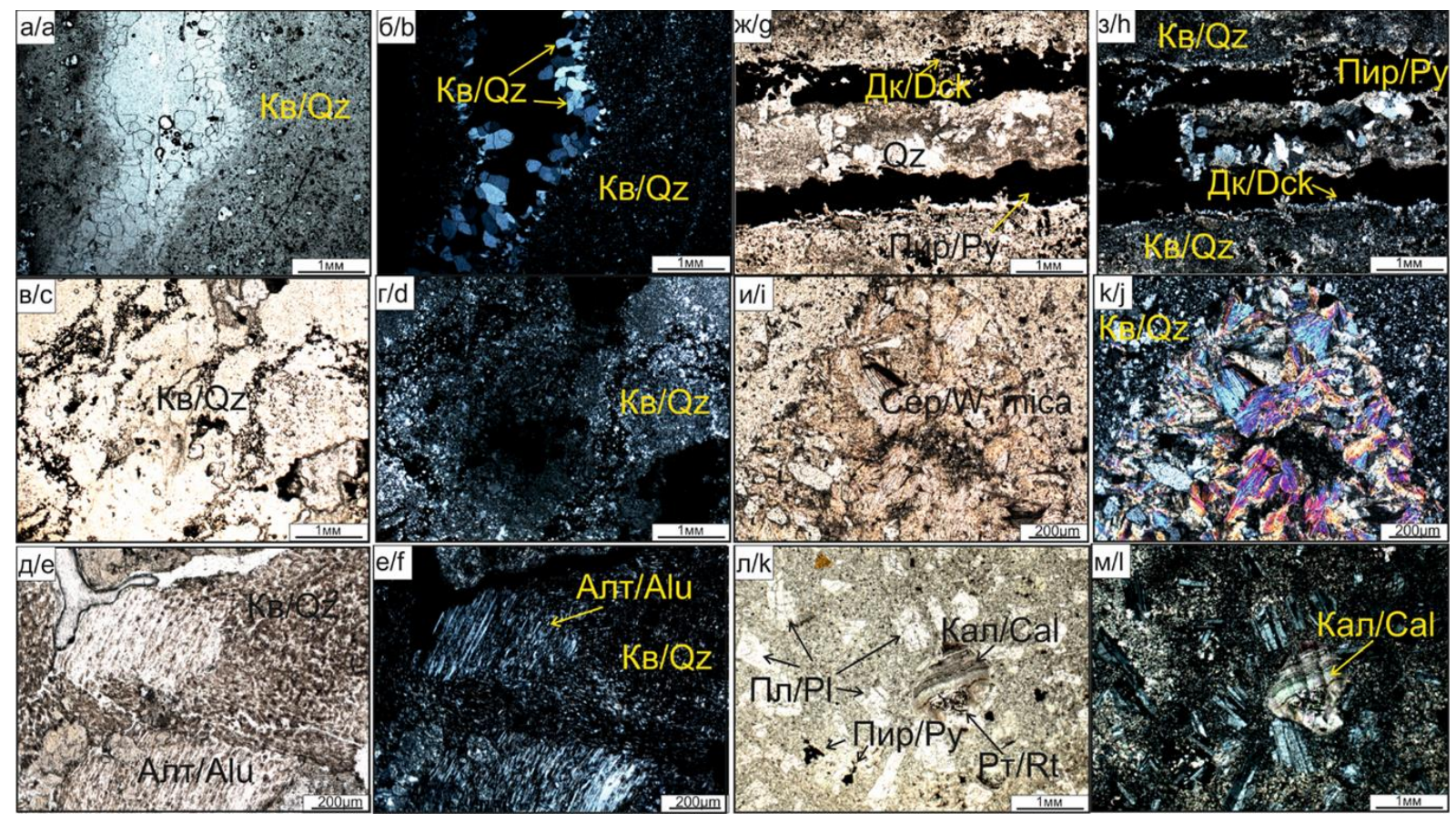

Рис. 4. Фотографии полированных илифов метасоматитов участка Эми в параллельных (а, в, д, ж, $и$, л) и скрещеенных (б, г, е, з, к, м) николях. Пористые монокварциты представлены кварием (Кв) различных морфологических типов - мозаичным и перистым (участок Эми, скв. 2, гл. 40,9 м) (а, б); брегчированные кваричиты с повышенной трещцинноватостью (участок Эми, скв. 2, гл. 109,8 м) (в, г); алунитовые (Алт) кварциты (участок Эми, скв. 2, гл. 13,6 м) (д, е); диккитовые (Дк) кварииты с прожилками пирита (Пир) (участок Эми, скв. 2, гл. 200 м) (ж, з); квари-серичитовые (Сер) метасоматиты (участок Эми, скв. 3, гл. 62,5 м) (и, к); метаандезиты с реликтовыми вкрапленниками плагиоклазов (Пл) на фоне измененной основной массы стекла с вкрапленностью пирита (Пир) неправильной формы и зональнымм зерном кальцита (Кал) с вкрапленностью игольчатого рутила (Рт) (участок Эми, скв. 4, гл. 21,8 м) (л, м)

Fig. 4. Transmitted-light microphotographs of altered rocks within the Emmy deposit in plane (a, $c, e, g, i, k)$ and crosspolarized $(b, d, f, h, j, l)$ light. Residual quartz $(Q z)$ with vuggy texture represented by mosaic and drusy varieties (d. Emmy, drill hole Em2, depth 40,9 m) $(a, b)$; brecciate residual quartz with fracture pattern (d. Emmy, drill hole Em2, depth 109,8 m) (c,d); quartz-alunite (Alu) zone (d. Emmy, drill hole Em2, depth 13,6 m) (e, f); quartz-dickite (Dck) zone with veinlets of pyrite (d. Emmy, drill hole Em2, depth $200 \mathrm{~m})(\mathrm{g}, \mathrm{h})$; quartz-white mica (W.mica) zone (d. Emmy, drill hole Em3, depth $62,5 \mathrm{~m})(i, j)$; altered andesites with disseminated irregularly shaped pyrite $(P y)$ and zonal grain of calcite (Cal) contained needles of rutile (Rt) (d. Emmy, drill hole Em4, depth 21,8 m) $(k, l)$

\section{Вещественный состав гипогенных сульфидов}

Преобладающим сульфидом гипогенной гидротермальной стадии формирования обоих участков эпитермального рудного поля Светлое является $n u$ pum $\quad\left(\mathrm{Fe}_{0,87-1,13}, \mathrm{Cu}_{0,0-0,12,}, \mathrm{As}_{0,0-0,02}, \mathrm{Sb}_{0,0-0,06}\right)\left(\mathrm{S}, \mathrm{Te}_{0,006}\right.$ $\left.0,03, \mathrm{Se}_{0,0-0,01}\right)_{2}$, а также сульфиды полиметаллов, пред-

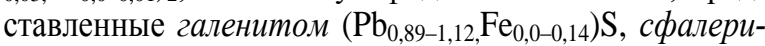
том $\left(\mathrm{Zn}_{0,74-1,0,} \mathrm{Fe}_{0,01-0,11}, \mathrm{Cu}_{0,01}, \mathrm{Na}_{0,19)} \mathrm{S}\right.$ и халькопиритом $\left(\mathrm{Cu}_{0,68-1,09}, \mathrm{Fe}_{0,66-1,19}\right) \mathrm{S}_{2}$, помимо перечисленных минералов широкое распространение, особенно в пределах участка Эми, получили блеклые руды ряда теннантит-тетраэдрита $\left(\mathrm{Cu}_{2,93-11,99}, \mathrm{Fe}_{0,0-6,44}, \mathrm{Zn}_{0-1,74}, \mathrm{Ag}_{0,0-0,36}\right)$
$\left(\mathrm{Sb}_{0,0-3,88}, \mathrm{As}_{0,0-4,0} \mathrm{Bi}_{0,0-0,51}, \mathrm{Te}_{0,0-2,68}\right) \mathrm{S}_{13} . \quad$ В пределах участка Елена пирит представлен преимущественно мелкими ( 5 мкм) кристаллами кубического габитуса, не обнаруживающими примесей. Кристаллы сфалерита, галенита, халькопирита и блеклых руд имеют аналогичную пириту размерность в первые мкм.

Участок Эми отличает разнообразие гипогенной сульфидной ассоциации и ее процентное содержание в рудоносных прожилках более 5 \%. Пирит представлен несколькими морфологическими типами: колломорфным и кристаллическим сложного пентагондодекаэдрического и тетраэдрического габитусов. Он обнаруживает примеси меди до 6,0 вес. \%, реже тел- 
лура, селена, сурьмы. В тесной ассоциации с таким пиритом находятся халькопирит, блеклые руды теннантин-тетраэдритового ряда, голдфилдит $\left(\mathrm{Cu}_{9,93-12,0}\right.$ $\left.\mathrm{Fe}_{0,0-1,74}, \mathrm{Ag}_{0-0,36}\right)\left(\mathrm{Te}_{1,41-2,68}, \mathrm{Sb}_{0,0-2,54}, \mathrm{Bi}_{0,0-0,28}, \mathrm{As}_{0,0-1,28}, \mathrm{~S}_{13}\right.$, хемусит $\left(\mathrm{Cu}_{5,46-6,27}, \mathrm{Fe}_{0,0-0,33}\right) \mathrm{Sn}_{0,75-1,07}\left(\mathrm{Mo}_{0,93-1,32}, \mathrm{Sb}_{0,0-0,27}\right) \mathrm{S}_{8}$, кавацулит $\mathrm{Bi}_{2,65-3,08} \mathrm{Te}_{2,88-3,3} \mathrm{Se}$, теллуриды никеля (мелонит $\mathrm{Ni}_{0,92-1,00} \mathrm{Te}_{2}$ ), свинца (алтаит $\mathrm{Pb}_{0,90} \mathrm{Te}$ ), висмута (теллуровисмутин $\mathrm{Bi}_{1,82-1,93} \mathrm{Te}_{3}$ ), сурьмы и висмута (теллурантимон $\mathrm{Sb}_{1,65-2,2,} \mathrm{Bi}_{0,15-0,7} \mathrm{Te}_{3}$ ), ртути (колорадоит $\left.\mathrm{Hg}_{0,77-0,94} \mathrm{Te}\right)$.

\section{Типы золотого оруденения}

Золотое оруденение эпитермального рудного поля Светлое представлено двумя типами: $\mathrm{Au}-\mathrm{Ag}$ и $\mathrm{Au}-\mathrm{Ag}-$ теллуридным. Первый тип оруденения развит как в пределах участка Елена, так и на участке Эми, при этом проба золота различна. Этот тип оруденения представлен первичными и окисленными (переотложенными) рудами. Зона окисления, содержащая окисленные руды, широко развита в пределах участка Елена и варьирует в пределах от 50 до 120 м, она определяется по охристо-желтому цвету и обильному развитию минералов зоны гипергенеза, таких как лимонит, ярозит, сепиолит, гиппсит, брушит, микасаит и т. д. Окисленные руды представлены переотложенным высокопробным золотом с пробой до 1000 \%, оно находится в ассоциации с самородным теллуром, селеном и т. д., гидроокислами железа и ярозитом и относится к гипергенному переотложенному этапу формирования.

В пределах участка Эми встречаются первичные руды Au-Ag типа со средней пробой около 900 \%, а также широко развит второй тип золотой минерализации, представленный теллуридами золота. Они обнаруживают определенную вертикальную зональность химического состава от наиболее высокосеребрянных разностей, представленных ютенбогаардтитом $\left(\mathrm{Ag}_{3,42-3,61} \mathrm{Au}_{0,67-0,74}, \mathrm{Fe}_{0,16-0,29}\right) \mathrm{S}_{2}, \mathrm{Te}_{0,07-0,12}$, штютцитом $\mathrm{Ag}_{4,43-5,14} \mathrm{Au}_{0,06-0,07}, \mathrm{Fe}_{0,6}, \mathrm{Bi}_{0,15} \mathrm{Te}_{3}$, мутманнитом $\mathrm{Au}_{0,55} \mathrm{Ag}_{1,26} \mathrm{Fe}_{0 \cdot 18} \mathrm{Mo}_{0,05} \mathrm{Te}_{2}$ и гесситом $\mathrm{Ag}_{1,71} \mathrm{Au}_{0 \cdot 1} \mathrm{Te}$, развитых в приповерхностных условиях $(38 \ldots 40 \mathrm{M})$ до наиболее обогащенных золотом на глубоких горизонтах $\left(198 \ldots 200\right.$ м) в виде калаверита $\mathrm{Au}_{0,71-0,91} \mathrm{Ag}_{0 \cdot 0-}$ ${ }_{0,19}, \mathrm{Fe}_{0,0-0,19}, \mathrm{Cu}_{0,0-0,15} \mathrm{Te}_{2}$. Промежуточная разновидность теллурида золота наиболее распространенная в пределах участка Эми представлена сильванитом $\mathrm{Au}_{0,86-1,67} \mathrm{Ag}_{0,4-2,31}, \mathrm{Fe}_{0,06-0,39}, \mathrm{Mo}_{0,2-0,77}, \mathrm{Ta}_{0,04-0,08} \mathrm{Te}_{4}$.

\section{Флюидный режим}

На современном уровне эрозионного среза в пределах рудного поля Светлое в формировании продуктивной залежи участвовал слабосоленый (0..0,5 мас. \% $\mathrm{NaCl}$-экв.) флюидный поток. Изученные двухфазовые включения установлены в позднем эвгедральном кварце перистого строения (рис. 5, ж-к, $6 a$, б), алуните (рис. 5, в), кальците (рис. 6, 2). Соотношение газовой и жидкой фазы для двухфазных включений равно 1:3, 2:3. Газовая фаза в подобных включениях, согласно данным Раман-спектроскопии, представлена диоксидом углерода. В зонах роста призматического кварца наличие одновременно захваченных газовых (рис. 6, d), газово-жидких и жидких включений (рис. 5, e-3) указывает на процесс кипения, протекавший во флюидной системе в момент кристаллизации минералов. Наличие различных форм диоксида кремния и его текстур свидетельствует о смене $\mathrm{pH}$ среды вследствие кипения. Так, в результате резкого вскипания и потери флюидом газовой составляющей растворимость кремнезема резко падает и отлагается аморфный и скрытокристаллический кварц с колломорфными и крустификационно-полосчатыми текстурами (рис. 5, г). Такая структура кварца не является благоприятной для захвата первичных флюидных включений, тем не менее о процессе можно судить по вторичным включениям в ранее образованных минералах. Так, в скрытокристаллическом кварце участка Елена были зафиксированы многочисленные газовые $\left(\mathrm{CO}_{2}\right)$ включения, состав которых диагностирован при помощи рамановского спектрометра, что подтверждает нахождение флюида в паровом (газовом) состоянии в момент формирования минерала. Учитывая совместное нахождение разнофазовых флюидных включений (на уровне одной пробы), минералообразующая система характеризовалась неоднократными условиями «вскипания» флюидов, источниками которых служили как гидротермальные потоки, так и метеорные воды, о чем свидетельствует низкая температура льда во вторичных включениях

В пределах участка Эми гидротермально-рудный процесс протекал при температурах $260 \ldots 340{ }^{\circ} \mathrm{C}$. Относительно крупный размер газово-жидких включений позволил проследить закономерное увеличение температур с глубиной в скв. 2. С двумя зонами максимальных температур гомогенизации в интервалах глубин 38...40 и 198...200 м связана интенсивная минерализация кварцитов. При этом по мере приближения по глубине к этим интервалам температура повышается. Так, в промежутке от $30 \ldots 40$ и от $50 \ldots 200$ м отмечается увеличение температуры гомогенизации газово-жидких включений от 260 до $340{ }^{\circ} \mathrm{C}$.

\section{Обсуждение результатов}

Метасоматическая зональность рудного поля Светлое и ее интерпретация

В пределах двух изучаемых участков - Елена и Эми - рудного поля Светлое, отражающих различный уровень эрозионного среза согласно принятым представлениям о моделях эпитермальных систем [21] выделяется осевая зона остаточного кварца (вторичные кварциты с различными текстурно-структурными особенностями - мозаичный, перистый, колломорфный, крустификационный) и ореол переслаивающихся линейно-вытянутых зон метасоматитов (алунитовые и диккитовые кварциты), сменяющихся на большем удалении от осевой зоны серицитовыми и иллит-хлоритовыми метасоматитами. Рудно-метасоматический процесс приурочен к дегазации средне-кислого магматического очага и накладывался на поля вулканитов. Металлонасыщенные флюиды поступали по зонам тектонического разуплотнения, кольцевым и радиальным разломам и в неравновесных условиях приводили к интенсивному преимущественно кислотному (местами близ нейтраль- 
ному) метасоматозу в кальдерах проседания, на склонах и у основания палеовулканических аппаратов. В результате формировался так называемый ореол вторичных кварцитов. Мощные и протяженные поля монокварци- тов, сменяющиеся алунитовыми кварцитами и наложением диккитовых или диккит-каолинитовых кварцитов в дистальном направлении переходят в хлоритовые, иллит-хлоритовые аргиллизиты.
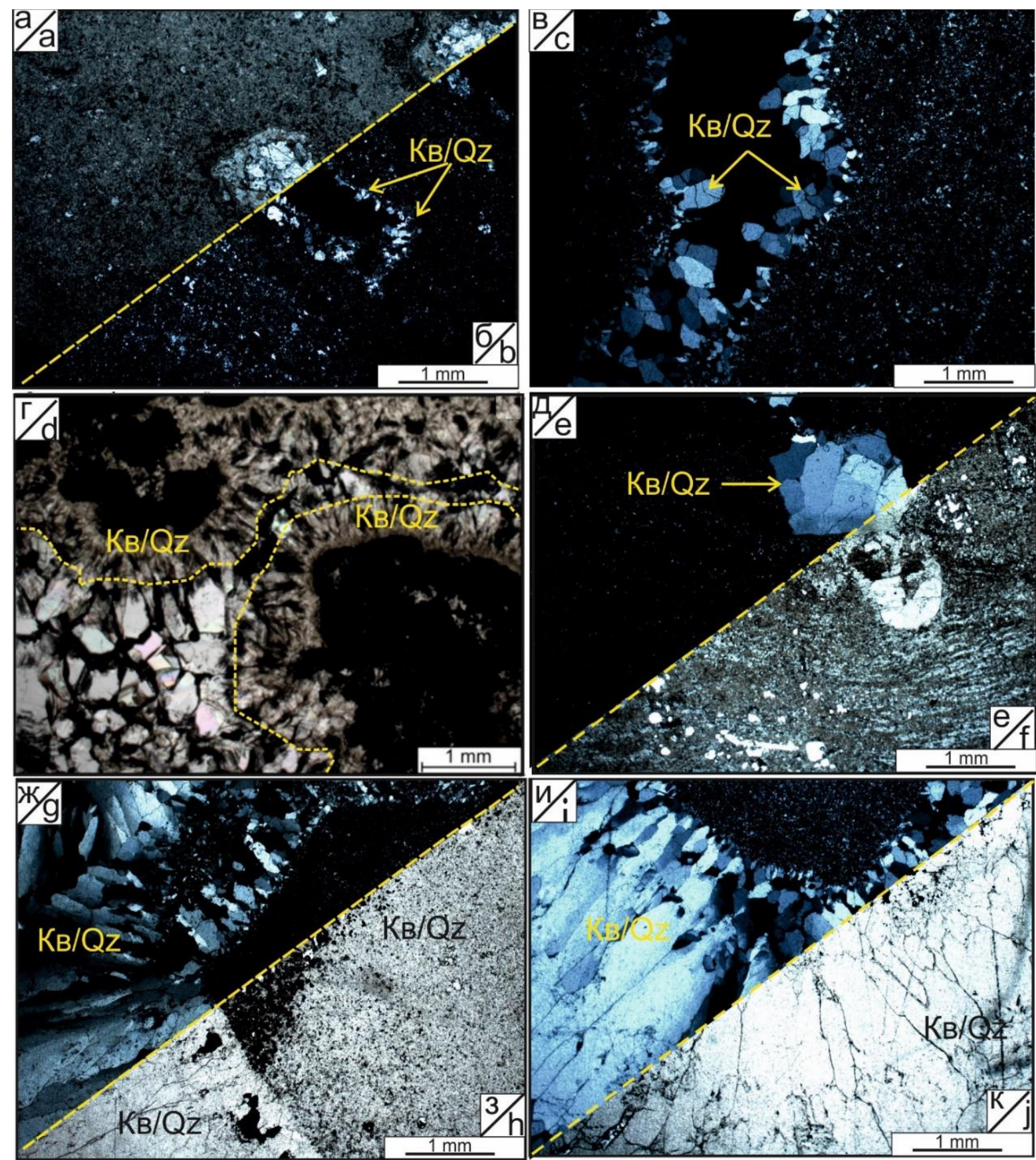

Pис. 5. Микрофотографии в проходямем $(a, 2, e, 3, \kappa)$ и отраженном $(б, 6, \partial, ж, и)$ свете текстурных особенностей жильного квариа (Кв): крустификационная (a-b); коломорфная (2); мозаичная (d, e); перистая (ж-к)

Fig. 5. Transmitted-light photomicrographs in plane- $(a, d, f, h, j)$ and cross-polarized $(b, c, e, g, i)$ light of vein quartz $(Q z)$ textures: crustified $(a-c)$; collomorphic $(d)$; mosaic $(e, f)$; feathery $(g-j)$

\section{Тип эпитермального оруденения}

Околорудный метасоматизм играет важную роль при установлении того или иного типа эпитермальных месторождений золота. Распространение вторичных кварцитов (с преобладанием остаточного кавернозного кварца) и аргиллизитов (с преобладанием алунита, диккита и пирофиллита) обычно характеризует «литокапы (lithocaps)», связанные с кислотносульфатными (HS) и умеренно-кислотными эпитермальными месторождениями (IS) [1, 2, 5, 10, 22-24]. Присутствие карбонатов в наименее измененных породах участка Эми является одним из свидетельств умеренно-кислотного режима (IS) [5, 25-28]. 

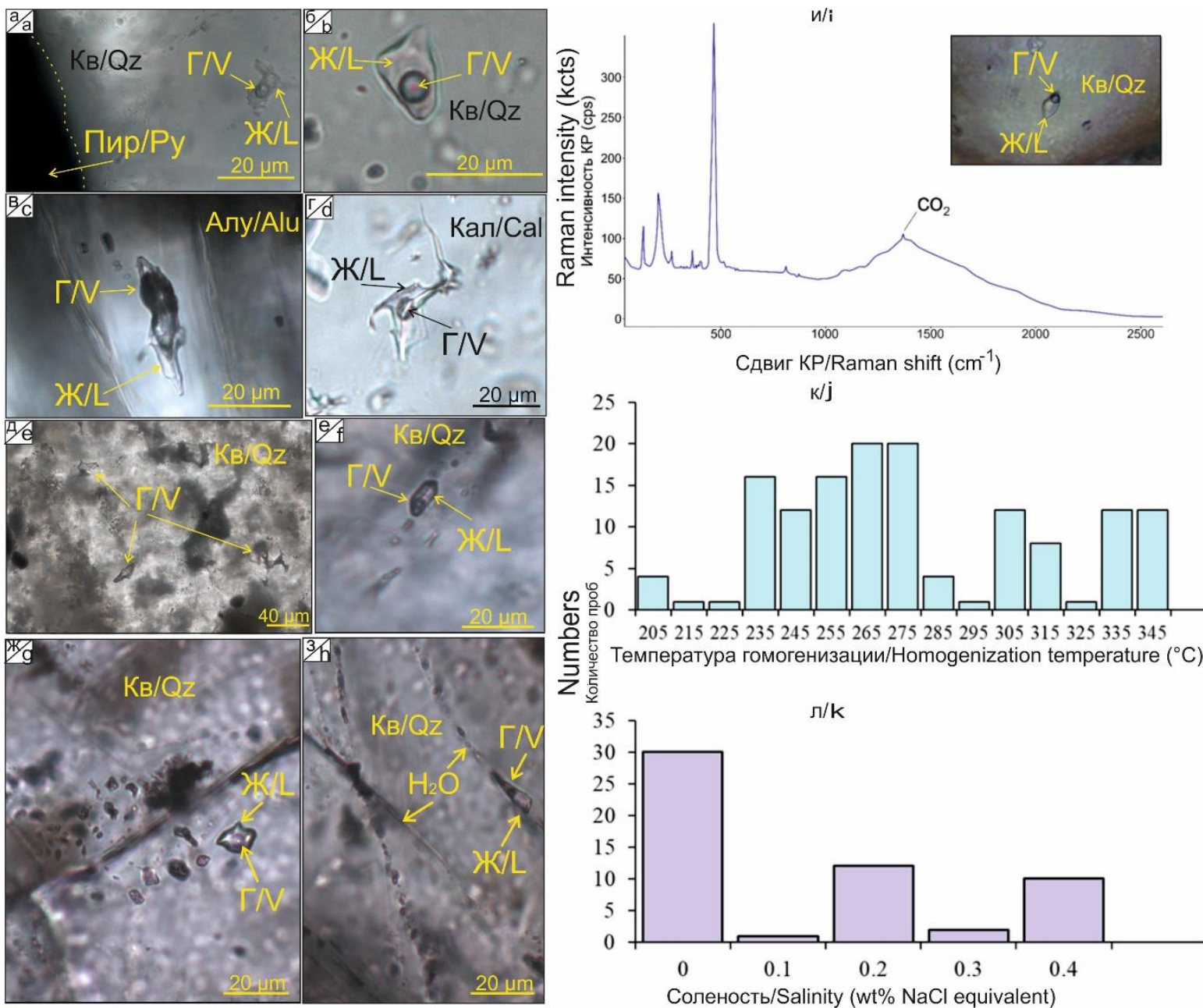

Pис. 6. Микрофотографии первичных газово(Г)-жидких(Ж) (а-г) и газовых(Г) (д) включений, захваченных в кварие (Кв) (а, б), алуните (Alu) (в), кальците (Kal) (2) и вторичных газово-жидких (e-з) и жидких (з) включениях, представленных водой $\left(\mathrm{H}_{2} \mathrm{O}\right)$, изученных в пределах рудного поля Светлое; (u) рамановский спектр, соответствующий углекислому газу, отражающий состав газа вторичных газово-жидких включений в кварие (Кв) (м. Елена). Суммарные диаграммы температур гомогенизации (к) и солености (л), полученные по включения рудного поля Светлое

Fig. 6. Microphotographs of primary vapor $(V)$-liquid $(L)(a-d)$ and vapor $(V)(e)$ fluid inclusions hosted in quartz $(Q z)(a, b)$, alunite $(\mathrm{Alu})(\mathrm{c})$ and calcite $(\mathrm{Cal})(d)$, and secondary vapor-liquid $(f-h)$ and liquid $(h)$ inclusions, represented by water $\left(\mathrm{H}_{2} \mathrm{O}\right)$, observed within the SED; Raman spectra of dioxide carbon reflecting gas composition of the secondary two-phase liquid and vapor rich inclusion (i) in quartz (d. Elena); summary histograms of (j) homogenization temperatures and $(k)$ salinity for inclusions of the SED

Учитывая тот факт, что в пределах участка Елена широко развиты алунитовые и диккитовые кварциты, этот участок по набору метасоматически-измененных пород соответствует кислотно-сульфатному (HS) типу. При этом участок Эми характеризует небольшое количество алунитовых кварцитов и преобладание вторичных кварцитов и аргиллизитов (рис. 2, Б), где широко распространены такие филлосиликаты, как серицит и иллит, что наиболее характерно для промежуточного умеренно-кислотного эпитермального (IS) типа. Преобладающими текстурами кварца являются колломорфная, мозаичная, крустификационная и перистая (эвгедральный кварц), характерные для HS-IS типов.

Типы эпитермальных месторождений идентифицируются не только на основе состава метасоматически-измененных пород, но и главным образом на ос- нове вещественного состава гипогенной сульфидной ассоциации [8].

Состав гипогенных сульфидов представлен главным образом сульфидами полиметаллов и теннантиттетраэдритом, при этом типичные сульфиды, отвечающие кислотно-сульфатному (HS) типу, такие как энаргит, люцонит, фаматинит, гипогенный ковеллин, установлены не были. Однако можно с определенной долей уверенности предположить, что (HS) гипогенные сульфиды могли быть эродированы на меньшей глубине или изменены до блеклых руд на современном уровне эрозионного среза в пределах участка Эми аналогично эпитермальному рудному полю Саммитвиля (Колорадо) $[29,30]$ и согласно существующим представлениям о эпитермальных системах в целом [21]. Содержание гипогенной сульфидной ассоциации в рудоносных жилах и прожилках 
участка Эми более 5 \%, что, согласно данным [27], характерный признак месторождений IS типа. По данным Ли Ванга [28] месторождения умереннокислотного типа зачастую имеют тесную связь с андезито-дацитовыми вулканогенно-субвулканическими породами, образованными в субдукционных обстановках на глубинах от $300 \ldots 1000$ м как результат известково-щелочного магматизма. Температуры гомогенизации газово-жидких включений варьируют в пределах от 150 до $350{ }^{\circ} \mathrm{C}$ аналогично полученным нами данным при проведении микрокриотермометрических экспериментов.

Таким образом, по особенностям проявления метасоматической зональности, ассоциации жильных минералов, вещественному составу гипогенных сульфидов и флюидному режиму эпитермальное 30лоторудное поле Светлое относится к «кислотноумеренно-кислотному сульфатному типу (HS-IS)» [31-33] аналогично Малетойваямскому полю центральной Камчатки [34-36], а также другим зарубежным аналогам, таким как месторожения ВикторияЛепанто (Филлипинские острова) [37]; Ресковское рудное поле (Венгрия) [38]; Перама-Хилл (Греция) [39]; Зиншиан (Китай) [40, 41], Мах-Ад-Дахаб (Саудовская Аравия) [42], Зехабад (Иран) [43].

В определенных случаях с месторождениями HSIS типа генетически связаны порфировые месторождения, которые являются корневыми частями единой гидротермальной системы [37-40].

\section{Выводы}

Зональность проявления гидротермальных изменений в пределах эпитермального рудного поля Светлое имеет следующие основные особенности:

1. Схема метасоматической зональности эпитермального рудного поля Светлое представлена следующей сменой метасоматитов от центральной

\section{СПИСОК ЛИТЕРАТУРЬ}

1. Lindgren W. Mineral deposits. - New York; London: McGrawHill Book Company, 1933. - $930 \mathrm{p}$.

2. White D.E. Thermal springs and epithermal ore deposits // Economic Geology. - 1955. - V. 55. - P. 99-154.

3. Henley R.W. Epithermal deposits in volcanic terranes // Gold Metallogeny and Exploration. - Glasgow: Blackie, 1991. P. 133-164.

4. Sillitoe R.H. Epithermal models, genetic types, geometrical controls and shallow features // Mineral Deposits Division, Special Paper. - Saint John's: Geological Association of Canada, 1993. P. 403-417.

5. White N.C., Hedenquist J.W., Epithermal gold deposits: styles, characteristics and exploration // SEG Newsletter. - 1995. V. 23. - P. 1-9.

6. Epithermal gold deposits: styles, characteristics and exploration / J.W. Hedenquist, E. Izawa, A. Arribas, N.C. White // Resource Geology. - 1996. - V. 1. - P. 1-15.

7. Hedenquist J.W., Arribas R.A. Exploration for epithermal gold deposits // Reviews in Economic Geology. - 2000. - V. 13. P. 245-277.

8. Sillitoe R., Hedenquist J. Linkages between volcanotectonic settings, ore-fluid compositions, and epithermal precious metal deposits // Society of Economic Geologists Special Public. 2003. - V. 10. - P. 315-343

9. Taylor B.E. Epithermal gold deposits // Mineral. Deposits of Canada: a synthesis of major deposit-types, district metallogeny, the evolution of geological provinces, and exploration methods / зоны к периферии: монокварциты $\rightarrow$ алунитовые кварциты $\rightarrow$ диккитовые кварциты $\rightarrow$ кварцгидрослюдистые аргиллизиты $\rightarrow$ пропилиты.

2. Жильный кварц представлен четырьмя текстурными разновидностями - крустификационный, мозаичный, перистый (эвгедральный), колломорфный. Установленная микрозональность кварца (колломорфный $\rightarrow$ мозаичный $\rightarrow$ перистый) отражает многоактное (или пульсационное) поступление флюидов.

3. В пределах залежи вторичных кварцитов отмечается приуроченность колломорфного и перистого кварца к пористым и, реже, массивным монокварцитам. Мозаичный и крустификационный кварц встречаются во всех типах вторичных кварцитов.

4. Состав гипогенной сульфидной минерализации представлен сульфидами полиметаллов $\mathrm{Cu}, \mathrm{Pb}, \mathrm{Zn}$, $\mathrm{Fe}$ в виде пирита, галенита, сфалерита, халькопирита и теннантит-тетраэдрита. В пределах учаска Эми минеральная ассоциация сульфидов гидротермальной стадии составляет более 5 об. \% и отличается разнообразием и обилием теллуридов.

5. Золотое оруденение представлено двумя типами: $\mathrm{Au}-\mathrm{Ag}$ и $\mathrm{Au}-\mathrm{Ag}$-теллуридным. Au-Ag руды представлены первичными рудами со средней пробой $\sim 900 \%$, развитыми в пределах участка Эми, вторичные (окисленные) руды с пробой до 1000\% преобладают на участке Елена.

6. По вещественному составу измененных пород, гипогенной сульфидной ассоциации и флюидному режиму эпитермальное поле Светлое относится к сульфатно- и умеренно-кислотному (HS-IS) типу, для которого характерна перспектива обнаружения порфирового оруденения на глубину.

Работа выполнена в рамках программы повымения конкурентоспособности ТПУ.

Ed. by W.D. Goodfellow. Mineral Deposits Division, Special Publication. - Saint John's, NL, Canada: Geological Association of Canada, 2007. - V. 5. - P. 113-139.

10. Exploration tools for linked porphyry and epithermal deposits: example from the Mankayan intrusion-centered $\mathrm{Cu}-\mathrm{Au}$ district, Luzon, Philippines / Z. Chang, J.W. Hedenquist, N.C. White, D.R. Cooke, M. Roach, C.L. Deyell, J.Jr. Garcia, J.B. Gemmell, S. McKnight, A.L. Cuison // Economic Geology - 2011. V. 106. - P. 1365-1398.

11. Lithocaps - characteristics, origins and significance for porphyry and epithermal exploration / D.R. Cooke, N.C. White, L. Zhang, Z. Chang, H. Chen // Mineral Resources to Discovery - 14 th SGA Biennial Meeting. - Quebec City, Canada, 2017. - V. 1. P. 291-294.

12. Кигай И.Н. Условия формирования метасоматитов и оруденения эпитермальных золото-серебрянных месторождений // Геология рудных месторождений. - 2020. - V. 62. - № 5. P. 475-480.

13. Cherkasova (Yakich) T., Kucherenko I., Abramova R. Rear polymineral zone of near-veined metasomatic aureole in mesothermal Zun-Holba gold deposit (Eastern Sayan) // IOP Conference Series: Earth and Environmental Science. - 2015. - V. 27 : Problems of Geology and Subsurface Development. - P. 1-5.

14. Estimating gold-ore mineralization potential within Topolninsk ore field (Gorny Altai) / T. Timkin, V. Voroshilov, O. Askanakova, T. Cherkasova, A. Chernyshov, T. Korotchenko // IOP Conference Series: Earth and Environmental Science. - 2015. - V. 27: Problems of Geology and Subsurface Development. - P. 1-6. 
15. The Okhotsk-Chukotka volcanic belt: age of its northern part according to new Ar-Ar and U-Pb geochronological data / P.L. Tikhomirov, V.V. Akinin, V.O. Ispolatov, P. Alexander, I.Y. Cherepanova, V.V. Zagoskin // Stratigraphy and Geological Correlation. - 2006. - V. 14. - P. 524-537.

16. Late Mesozoic silicic magmatism of the North Chukotka area (NE Russia): age, magma sources, and geodynamic implications / P.L. Tikhomirov, E.A. Kalinina, K. Kobayashi, E. Nakamura // Lithos. - 2008. - V. 105. - P. 329-346.

17. Ананьев Ю.С., Житков В.Г., Поцелуев А.А. Дистанционная прогнозно-поисковая модель эпитермальных $\mathrm{Au}-\mathrm{Ag}$ месторождений (на примере рудного поля Светлое, Хабаровский край) // Известия Томского политехнического университета. Инжиниринг георесурсов. - 2019. - Т. 330. - № 5. - С. 84-92.

18. Мишин Л.Ф. Вторичные кварциты и их связь с золоторудной минерализацией месторождения Светлое (Россия) (Ульинский прогиб, Охотско-Чукотский вулканогенный пояс) // Тихоокеанская геология. - 2011. - Т. 30. - № 4. - С. 32-48.

19. Геодинамика, магматизм и металлогения Востока России под ред. А.И. Ханчука. - Владивосток: Даль-наука, 2006. $981 \mathrm{c}$.

20. Mineral textures and fluid inclusion petrography of the epithermal $\mathrm{Ag}-\mathrm{Au}$ deposits at Guanajuato, Mexico: application to exploration / D. Moncada, S. Mutchler, A. Nieto, T.J. Reynolds, J.D. Rimstidt, R.J. Bodnar // Journal of Geochemical Exploration. - 2012. V. 114 - P. 20-35.

21. Hedenquist J.W., Taran Y.A. Modeling the formation of advanced argillic lithocaps: Volcanic vapor condensation above porphyry intrusions // Economic Geology. - 2013. - V. 108. - P. 1523-1540.

22. Sillitoe R.H. Metallic mineralization affiliated to subaeria volcanism // Geological Society Special Publication. - 1977. V. 7 (1) - P. 99-116.

23. Sillitoe R.H. Epithermal models; genetic types, geometrica controls and shallow features // Special Papers. - Saint John's: The Geological Association of Canada, 1993. - P. 403-417.

24. Hedenquist J.W., Henley R.W. The importance of $\mathrm{CO}_{2}$ on freezing point measurements of fluid: evidence from active geothermal systems and implications for epithermal ore deposition // Economic Geology. - 1985. - V. 80. - P. 1379-1406.

25. Heald P., Foley N.K., Hayba D.O. Comparative anatomy of volcanic-hosted epithermal deposits: acid- sulfate and adulariasericite types // Economic Geology. - 1987. - V. 82. - P. 1-26.

26. Epithermal gold deposits: styles, characteristics and exploration / J.W. Hedenquist, E. Izawa, A. Arribas, N.C. White // Publications Society of Economic Geologists News. - 1995. - V. 1. - P. 9-13.

27. Basic characteristics and research progresses of intermediate sulfidation type epithermal gold polymetallic Deposits and prospects / G.X. Song, K.Z. Qin, G.M. Li, L. Wang // Acta Petrologica Sinica. - 2018. - V. 34. - P. 748-762.

28. A review of intermediate sulfidation epithermal deposits and subclassification / L. Wang, K.Z. Qin, G.X. Song, G.M. Li // Ore Geology Reviews. - 2019. - V. 107. - P. 434-456.

29. Steven T.A., Ratte J.C. Geology and ore deposits of the Summitville District, San Juan Mountains, Colorado. United States Geological Survey Professional Paper. - Washington, NL, Canada: Geological Association of Canada, 1960. - V. 343. - 70 p

30. Stoffregen R. Genesis of acid-sulfate alteration and $\mathrm{Au}-\mathrm{Cu}-\mathrm{Ag}$ mineralization at Summitville, Colorado // Economic Geology. 1987. - V. 82. - P. 1575-1591.
31. Sillitoe R.H. Styles of high-sulphidation gold, silver and copper mineralization in porphyry and epithermal environments // AusIMM Proceedings 306. - Bali: Indonesia, 1999. - P. 19-34.

32. Arribas A. Characteristics of high-sulfidation epithermal deposits, and their relation to magmatic fluid // Mineralogical Association of Canada Short Course Series. - 1995. - V. 23. - P. 419-454.

33. Mineralogy of the Svetloye epithermal district, Okhotsk-Chukotka volcanic belt, and its insights for exploration / T.Yu. Yakich, Y.S. Ananyev, A.S. Ruban, R.Y. Gavrilov, D.V. Lesnyak, D.V. Levochskaia, O.V. Savinova, M.A. Rudmin // Ore Geology Reviwes. - 2021. - V. 136. - 104257.

34. $\mathrm{Au}(\mathrm{Ag})-\mathrm{Se}-\mathrm{Te}-\mathrm{S}-\mathrm{Cu}-\mathrm{Sb}-\mathrm{As}-\mathrm{Bi}$ mineralization at the Maletoyvayam deposit (Central Kamchatka, Russia) and physicochemical conditions of its formation / E.G. Sidorov, A.A. Borovikov, N.D. Tolstykh, D.S. Bukhanova, G.A. Palyanova, V.M. Chubarov // Minerals. - 2020. - V. 10. - P. 1-19.

35. Shapovalova M., Tolstykh N., Bobrova O. Chemical composition and varieties of sulfosalts from gold mineralization in the Gaching ore occurrence (Maletoyvayam ore field) // IOP Conference Series: Earth and Environmental Science. - 2019. - V. 319. - P. 7-16.

36. Mustard gold of the gaching ore deposit (Maletoyvayam ore field, Kamchatka, Russia) / N.D. Tolstykh, G.A. Palyanova, O.V. Bobrova, E.G. Sidorov // Minerals. - 2019. - V. 9. - P. 1-18.

37. Claveria R.J.R. Mineral paragenesis of the Lepanto copper and gold and the Victoria gold deposits, Mankayan Mineral District, Philippines // Resource Geology. - 2001. - V. 51. - P. 97-106.

38. Ore mineralogy and fluid inclusion constraints on the temporal and spatial evolution of a high-sulfidation epithermal $\mathrm{Cu}-\mathrm{Au}-\mathrm{Ag}$ deposit in the Recsk ore complex, Hungary / Á. Takács, F. Molnár, J. Turi, A. Mogessie, J.C. Menzies // Economic Geology. - 2017 V. 112. - P. 1461-1481.

39. Mineralogy and geochemical environment of formation of the Perama Hill high-sulfidation epithermal Au-Ag-Te-Se deposit, Petrota Graben, NE Greece / P.C. Voudouris, V. Melfos, P.G. Spry, R. Moritz, C. Papavassiliou, G. Falalakis // Mineralogy and Petrology. - 2011 - V. 103. - P. 79-100

40. Geology and fluid inclusion geochemistry of the Zijinshan highsulfidation epithermal $\mathrm{Cu}-\mathrm{Au}$ deposit, Fujian Province, SE China: implication for deep exploration targeting / J. Zhong, Y.-J. Chen, J. Chen, J.-P. Qi, M.-C. Dai // Journal of Geochemical Exploration. - 2018. - V. 184. - P. 49-65.

41. Spatial distribution and variation of ore body, alteration and oreforming fluid of the giant Zijinshan epithermal $\mathrm{Cu}-\mathrm{Au}$ deposit, SE China: implication for mineral exploration / J.-Y. Pan, P. Ni, Z. Chi, Y.-L. Yang, S.-N. Li, T. Bao, W.-B. Wang, W. Zeng, K. Xue // Geochemistry: Exploration, Environment, Analysis. 2018. - V. 18. - P. 279-293.

42. Geology, mineralogy and genesis of the world-class Mahd Adh Dhahab epithermal Au-(Ag)-telluride deposit, Kingdom of Saudi Arabia / S.A. El-shafei, K.M. Abdel-Maksoud, H.M. Helmy, A.H. Ahmed // Journal of Asian Earth Sciences. - 2020. V. 201. -104510

43. Shahbazi S., Ghaderi M., Alfonso P. Mineralogy, alteration, and sulfur isotope geochemistry of the Zehabad intermediatesulfidation epithermal deposit, NW Iran // Turkish Journal of Earth Sciences. - 2019. - V. 28. - P. 882-901.

Поступила 25.08.2021 2.

\section{Информация об авторах}

Левочская Д.В., аспирант отделения геологии Инженерной школы природных ресурсов Национального исследовательского Томского политехнического университета; начальник отдела поисковых работ Хабаровского филиала АО «Полиметалл УК».

Якич Т.Ю., кандидат геолого-минералогических наук, доцент отделения геологии Инженерной школы природных ресурсов Национального исследовательского Томского политехнического университета.

Лесняк Д.В., аспирант отделения геологии Инженерной школы природных ресурсов Национального исследовательского Томского политехнического университета; начальник управления минерально-сырьевых ресурсов Хабаровского филиала АО «Полиметалл УК».

Ананьев Ю.С., доктор геолого-минералогических наук, доцент отделения геологии Инженерной школы природных ресурсов Национального исследовательского Томского политехнического университета. 
UDC 552.113

\title{
HYDROTHERMAL-ALTERED ZONING, FLUID CONDITIONS, AND TYPES OF GOLD MINERALIZATION WITHIN THE ELENA AND EMY DEPOSITS OF THE EPITHERMAL SVETLOE ORE DISTRICT (KHABAROVSK TERRITORY)
}

\author{
Darya V. Levochskaya1,2, \\ levochskayaDV@polymetal.ru
}

\section{Tamara Yu. Yakich ${ }^{1}$,} cherkasovatu@tpu.ru

Dmitry V. Lesnyak ${ }^{1,2}$, lesnyakdv@polymetal.ru

\section{Yuriy S. Ananiev ${ }^{1}$,} AnanyevYS@tpu.ru

1 National Research Tomsk Polytechnic University, 30, Lenin avenue, Tomsk, 634050, Russia.

2 JSC Polymetal Management, Khabarovsk branch, 18, Muravev-Amursky street, Khabarovsk, 680000, Russia.

The relevance of the study is determined by obtaining new data concerning mineral composition, textural and structural features, hydrothermal-metasomatic zoning, fluid regime, and types of gold mineralization of two most contrasting areas of the Svetloe epithermal district (Khabarovsk Territory), formed in different-aged parent rocks of the Late Cretaceous age $\left(K_{2}\right)$ of the Khetanian Formation basic composition in the Cognac-Santonian Stage (d. Emmy) and discordant bedding felsic rocks of the Urak Formation of the Campanian-Maastrichian Stage (d. Elena). The selected objects are characterized by different levels of zone erosion and most fully reflect the diversity of altered rocks of the Svetloe epithermal district. Altered rock represented by weakly altered rocks of the Khetanian Formation within the Emmy deposit and strongly altered, including hypergene processes, acidic rocks prevailing on the territory of the Elena deposit. The data obtained play an important role in establishing the type of epithermal deposits, forecasting mineralization at depth, and can also be used to identify search criteria and features of similar objects both in the Okhotsk-Chukotka volcanic belt and beyond. The aim of this work is to study the hydrothermal-metasomatic zoning, material composition, textural and structural features, fluid regime, as well as the forms of gold occurrence in the Svetloe epithermal ore district using the Emmy and Elena deposits as example. The objects of the study are ores, metasomatites and weakly altered parental rocks in the form of core, ore and chipped samples taken as a result of research work from eight wells and two operating open pits. The rocks were studied by optical and electron microscopy methods using energy dispersive spectroscopy, as well as by X-ray diffraction analysis, microthermometry, and Raman spectrometry. As a result of the studies, it has been established that the altered zoning of the Svetloe epithermal district includes an axial zone of residual quartz with various texture and structural features - mosaic, feathered, collomorphic, and crustifying structure and a halo of interbedded linearly elongated zones of altered rocks composed of alunite-and dickite-quartz zone, which are replaced at more distance from the axial zone by sericite and illite-chlorite zones of the propylite formation, with a lesser degree of elaboration of volcanic and volcanicclastic rocks of the acid composition of the Urak Formation, the ore-containing area of the Elena, and of intermediate and basic composition including the Emmy deposit. The main part of mineralization is associated with the residual quartz zone. The morphology of ore bodies is represented by sub-layer linear keeled deposits with mushroom-like swells in paleo-grooves up to $110 \mathrm{~m}$. The average thickness of ore bodies varies from 12 to $60 \mathrm{~m}$, up to $700 \mathrm{~m}$ long, and $100 . .240 \mathrm{~m}$ wide. The fall of the ore zones is gentle, steep near the paleo-grooves with uneven or very uneven distribution of the valuable component. The average grade of gold in ores is $2,5 \mathrm{~g} / \mathrm{t}$. The composition of hypogene sulfide mineralization is represented by sulfides of polymetals $\mathrm{Cu}, \mathrm{Pb}, \mathrm{Zn}, \mathrm{Fe}$ in the mineral form of pyrite, galena, sphalerite, chalcopyrite, and tennantite-tetrahedrite. Within the ore bodies of the Emmy deposit, the mineral association of sulfides of the hydrothermal stage is more than 5 vol. \% and distinguished by the diversity and abundance of tellurides. Gold mineralization is represented by two types: $A u-A g$ and $A u-A g-$ telluride. Au-Ag ores are represented by primary ores with an average fineness of $\sim 900 \%$ developed within the Emmy deposit and secondary (oxidized) ores with a fineness of up to $1000 \%$ prevailing at the Elena deposit. According to the results of the study of vapor-liquid inclusions in quartz, the hydrothermal-ore process at the Emmy deposit proceeded at $260 \ldots 330{ }^{\circ} \mathrm{C}$. Microcryothermometric experiments of the Elena deposit indicate the $200 . .240{ }^{\circ} \mathrm{C}$ range of the hydrothermal process. In terms of the material composition of altered rocks, hypogene sulfide association, and fluid regime, the Svetloe epithermal district belongs to the sulfate-acid and medium-acid (HS-IS) type, showing the prospect of detecting porphyry mineralization at depth.

\section{Key words:}

Hydrothermal-altered zoning, epithermal gold deposits, textural and structural features, fluid conditions, Svetloe epithermal ore district, Okhotsk-Chukotka volcanic belt.

The research was carried out within the TPU Competitiveness Enhancement Program.

\section{REFERENSES}

1. Lindgren W. Mineral deposits. New York, London, McGraw-Hill Book Company, 1933. $930 \mathrm{p}$.
2. White D.E. Thermal springs and epithermal ore deposits. Economic Geology, 1955, vol. 55, pp. 99-154.

3. Henley R.W. Epithermal deposits in volcanic terranes. Gold Metallogeny and Exploration. Glasgow, Blackie, 1991. pp. 133-164. 
4. Sillitoe R.H. Epithermal models, genetic types, geometrical controls and shallow features. Special Paper. Saint John's, Geological Association of Canada, 1993. pp. 403-417.

5. White N.C., Hedenquist J.W. Epithermal gold deposits: styles, characteristics and exploration. SEG Newsletter, 1995, vol. 1, pp. 913 .

6. Hedenquist J.W., Izawa E., Arribas A., White, N.C. Epithermal gold deposits: styles, characteristics and exploration. Resource Geology, 1996, vol. 1, pp. 9-13

7. Hedenquist J.W., Arribas R.A. Exploration for epithermal gold deposits. Reviews in Economic Geology, 2000, vol. 13, pp. 245-277.

8. Sillitoe R., Hedenquist J. Linkages between volcanotectonic settings, ore-fluid compositions, and epithermal precious metal deposits. Society of Economic Geologists Special Public, 2003, vol. 10, pp. 315-343.

9. Taylor B.E. Epithermal gold deposits. Mineral. Deposits of Canada: a synthesis of major deposit-types, district metallogeny, the evolution of geological provinces, and exploration methods. Ed. by W.D. Goodfellow. Mineral Deposits Division, Specia Publication; Saint John, NL, Canada, Geological Association of Canada, 2007. Vol. 5, pp. 113-139.

10. Chang Z., Hedenquist J.W., White N.C., Cooke D.R., Roach M., Deyell C.L., Garcia J., Jr., Gemmell J.B., McKnight S., Cuison A.L. Exploration tools for linked porphyry and epithermal deposits: Example from the Mankayan intrusion-centered $\mathrm{Cu}-\mathrm{Au}$ district, Luzon, Philippines. Economic Geology, 2011, vol. 106 , pp. $1365-1398$.

11. Cooke D.R., White N.C., Zhang L., Chang Z., Chen H., Lithocaps characteristics, origins and significance for porphyry and epithermal exploration. Mineral Resources to Discovery - 14th SGA Biennial Meeting. Quebec City, Canada, 2017. Vol. 1, pp. 291-294.

12. Kigay I.N. Conditions for the formation of metasomatites and mineralization of epithermal gold-silver deposits. Geology of Ore Deposits, 2020, vol. 62, Iss. 5, pp. 475-480. In Rus.

13. Cherkasova (Yakich) T., Kucherenko I., Abramova R. Rear polymineral zone of near-veined metasomatic aureole in mesothermal Zun-Holba gold deposit (Eastern Sayan). IOP Conference Series: Earth and Environmental Science, 2015, vol. 27. Problems of Geology and Subsurface Development. pp. 1-5.

14. Timkin T., Voroshilov V., Askanakova O., Cherkasova (Yakich) T., Chernyshov A., Korotchenko T. Estimating gold-ore mineralization potential within Topolninsk ore field (Gorny Altai) IOP Conference Series: Earth and Environmental Science, 2015, vol. 27. Problems of Geology and Subsurface Development. pp. 1-6.

15. Tikhomirov P.L., Akinin V. V., Ispolatov V.O., Alexander P., Cherepanova I.Y., Zagoskin V.V. The Okhotsk-Chukotka volcanic belt: age of its northern part according to new $\mathrm{Ar}-\mathrm{Ar}$ and $\mathrm{U}-\mathrm{Pb}$ geochronological data. Stratigraphy and Geological Correlation, 2006, vol. 14, pp. 524-537.

16. Tikhomirov P.L., Kalinina E.A., Kobayashi K., Nakamura E. Late Mesozoic silicic magmatism of the North Chukotka area (NE Russia): age, magma sources, and geodynamic implications. Lithos 2008, vol. 105, pp. 329-346.

17. Ananyev Y.S., Zhitkov V.G., Potseluev A.A. Forecasting and prospecting model of epithermal high sulfidation $\mathrm{Au}-\mathrm{Ag}$ deposits using modern satellite data (on the example of ore field svetloe, Khabarovskiy kray). Bulletin of the Tomsk Polytechnic University. Geo Assets Engineering, 2019, vol. 330, no. 5, pp. 84-92. In Rus.

18. Mishin L.F. Secondary quartzites and their relation to gold ore mineralization of the Svetloye deposit (Ulya trough, OkhotskChukotka volcanogenic belt). Russian journal of pacific geology, 2011, vol. 30, pp. 32-48. In Rus.

19. Geodinamika, magmatism $i$ metallogeniya Vostoka Rossii [Geodynamics, magmatism, and metallogeny of the Russian East]. Ed. by A.I. Khanchuk. Vladivostok, Dalnauka Publ., 2006. 981 p.

20. Moncada D., Mutchler S., Nieto A., Reynolds T.J., Rimstidt J.D., Bodnar R.J. Mineral textures and fluid inclusion petrography of the epithermal $\mathrm{Ag}-\mathrm{Au}$ deposits at Guanajuato, Mexico: Application to exploration. Journal of Geochemical Exploration, 2012, vol. 114, pp. 20-35.

21. Hedenquist J.W., Taran Y.A., Modeling the formation of advanced argillic lithocaps: Volcanic vapor condensation above porphyry intrusions. Economic Geology, 2013, vol. 108, pp. 1523-1540.
22. Sillitoe R.H. Metallic mineralization affiliated to subaerial volcanism. Geological Society Special Publication, 1977, vol. 7 (1), pp. 99-116.

23. Sillitoe R.H. Epithermal models; genetic types, geometrical controls and shallow features. Special Papers. Saint John's, The Geological Association of Canada, 1993. pp. 403-417.

24. Hedenquist J.W., Henley R.W. The importance of $\mathrm{CO}_{2}$ on freezing point measurements of fluid: evidence from active geothermal systems and implications for epithermal ore deposition. Economic Geology, 1985, vol. 80, pp. 1379-1406.

25. Heald P., Foley N.K., Hayba D.O. Comparative anatomy of volcanic-hosted epithermal deposits: acid- sulfate and adulariasericite types. Econmic Geology, 1987, vol. 82, pp. 1-26.

26. Hedenquist J.W., Izawa E., Arribas A., White N.C. Epithermal gold deposits: styles, characteristics and exploration. Publications Society of Economic Geologists News, 1995, vol. 1, pp. 9-13.

27. Song G.X., Qin K.Z., Li G.M., Wang L. Basic characteristics and research progresses of intermediate sulfidation type epithermal gold polymetallic deposits and prospects. Acta Petrologica Sinica, 2018, vol. 34, pp. 748-762.

28. Wang L., Qin K.Z., Song G.X., Li G. M. A review of intermediate sulfidation epithermal deposits and subclassification. Ore Geology Reviews, 2019, vol. 107, pp. 434-456.

29. Steven T.A., Ratte J.C. Geology and ore deposits of the Summitville District, San Juan Mountains, Colorado. United States Geological Survey Professional Paper. 343, Washington, NL, Canada, Geological Association of Canada, 1960.70 p.

30. Stoffregen R. Genesis of acid-sulfate alteration and $\mathrm{Au}-\mathrm{Cu}-\mathrm{Ag}$ mineralization at Summitville, Colorado. Economic Geology, 1987, vol. 82, pp. $1575-1591$.

31. Sillitoe R.H. Styles of high-sulphidation gold, silver and copper mineralization in porphyry and epithermal environments [AusIMM Proceedings 306]. Bali, Indonesia, 1999. pp. 19-34.

32. Arribas A. Characteristics of high-sulfidation epithermal deposits, and their relation to magmatic fluid. Mineralogical Association of Canada Short Course Series, 1995, vol. 23, pp. 419-454

33. Yakich T.Y., Ananyev Y.S., Ruban A.S., Gavrilov R.Y., Lesnyak D.V., Levochskaia D.V., Savinova O.V., Rudmin M.A. Mineralogy of the Svetloye epithermal district, Okhotsk-Chukotka volcanic belt, and its insights for exploration Ore Geol. Rev., 2021, vol. 136, 104257.

34. Sidorov E.G., Borovikov A.A., Tolstykh N.D., Bukhanova D.S., Palyanova G.A., Chubarov V.M. Au(Ag)-Se-Te-S-Cu-Sb-As-Bi mineralization at the Maletoyvayam deposit (Central Kamchatka, Russia) and physicochemical conditions of its formation. Minerals, 2020, vol. 10, pp. 1-19.

35. Shapovalova M., Tolstykh N., Bobrova O. Chemical composition and varieties of sulfosalts from gold mineralization in the Gaching ore occurrence (Maletoyvayam ore field). IOP Conference Series: Earth and Environmental Science, 2019, vol. 319, pp. 7-16.

36. Tolstykh N.D., Palyanova G.A., Bobrova O. V., Sidorov E.G. Mustard gold of the gaching ore deposit (Maletoyvayam ore field, Kamchatka, Russia). Minerals, 2019, vol. 9, pp. 1-18.

37. Claveria R.J.R. Mineral paragenesis of the Lepanto copper and gold and the Victoria gold deposits, Mankayan Mineral District, Philippines. Resource Geology, 2001, vol. 51, pp. 97-106.

38. Takács A., Molnár F., Turi J., Mogessie A., Menzies J.C. Ore mineralogy and fluid inclusion constraints on the temporal and spatial evolution of a high-sulfidation epithermal $\mathrm{Cu}-\mathrm{Au}-\mathrm{Ag}$ deposit in the Recsk ore complex, Hungary. Economic Geology, 2017, vol. 112, pp. 1461-1481.

39. Voudouris P.C., Melfos V., Spry P.G., Moritz R., Papavassiliou C., Falalakis G. Mineralogy and geochemical environment of formation of the Perama Hill high-sulfidation epithermal Au-AgTe-Se deposit, Petrota Graben, NE Greece. Mineralogy and Petrology, 2011, vol. 103, pp. 79-100.

40. Zhong J., Chen Y.-J., Chen J., Qi J.-P., Dai M.-C. Geology and fluid inclusion geochemistry of the Zijinshan high-sulfidation epithermal $\mathrm{Cu}-\mathrm{Au}$ deposit, Fujian Province, SE China: implication for deep exploration targeting. Journal of Geochemical Exploration, 2018, vol. 184, pp. 49-65.

41. Pan J.-Y., Ni P., Chi Z., Yang Y.-L., Li S.-N., Bao T., Wang W.B., Zeng W., Xue K. Spatial distribution and variation of ore body, alteration and ore-forming fluid of the giant Zijinshan epithermal $\mathrm{Cu}-\mathrm{Au}$ deposit, SE China: implication for mineral exploration. 
Geochemistry: Exploration, Environment, Analysis, 2018, vol. 18, pp. 279-293.

42. El-shafei S.A., Abdel-Maksoud K.M., Helmy H.M., Ahmed A.H Geology, mineralogy and genesis of the world-class Mahd Adh Dhahab epithermal Au-(Ag)-telluride deposit, Kingdom of Saudi Arabia. Journal of Asian Earth Sciences, 2020, vol. 201, 104510.
43. Shahbazi S., Ghaderi M., Alfonso P. Mineralogy, alteration, and sulfur isotope geochemistry of the Zehabad intermediatesulfidation epithermal deposit, NW Iran. Turkish Journal of Earth Sciences, 2019, vol. 28, pp. 882-901.

Received: 25 August 2021.

\section{Information about the authors}

Darya V. Levochskaya, postgraduate student, National Research Tomsk Polytechnic University; head of prospecting geological works department, JSC Polymetal Management, Khabarovsk branch.

Tamara Yu. Yakich, Cand. Sc., associate professor, National Research Tomsk Polytechnic University.

Dmitry V. Lesnyak, postgraduate student, National Research Tomsk Polytechnic University; head of Mineral resources department, JSC Polymetal Management, Khabarovsk branch.

Yuriy S. Ananiev, Dr. Sc., associate professor, National Research Tomsk Polytechnic University. 